\title{
Article \\ Differential Interferometry over Sentinel-1 TopSAR Images as a Tool for Water and Tillage Soil Erosion Analysis
}

\author{
Francisco A. Sánchez-Crespo ${ }^{1}$, José Rafael Marques da Silva ${ }^{2,3}{ }^{\circledR}$, Maria T. Gómez-Villarino ${ }^{4}{ }^{\circledR}$, \\ Eutiquio Gallego ${ }^{4}\left(\mathbb{D}\right.$, José M. Fuentes ${ }^{4}\left(\mathbb{D}\right.$, Ana I. García ${ }^{4}$ and Francisco Ayuga ${ }^{4, *(\mathbb{D}}$ \\ 1 Departamento de Ingeniería Agroforestal, Escuela Técnica Superior de Ingeniería Agronómica, Alimentaria y \\ de Biosistemas, Campus Ciudad Universitaria, Universidad Politécnica de Madrid, 28040 Madrid, Spain; \\ francisco.screspo@alumnos.upm.es \\ 2 Mediterranean Institute for Agriculture, Environment and Development (MED), Department of Rural \\ Engineering, School of Science and Technology, University of Évora, 7000-671 Évora, Portugal; \\ jmsilva@uevora.pt or rafael@agroinsider.com \\ 3 Agroinsider Lda., PITE, R. Circular Norte, NERE, Sala 18, 7005-841 Évora, Portugal \\ 4 BIPREE Research Group, Universidad Politécnica de Madrid, 28040 Madrid, Spain; \\ teresa.gomez.villarino@upm.es (M.T.G.-V.); eutiquio.gallego@upm.es (E.G.); jm.fuentes@upm.es (J.M.F.); \\ ai.garcia@upm.es (A.I.G.) \\ * Correspondence: francisco.ayuga@upm.es or gi.eipirma@upm.es
}

\section{check for}

updates

Citation: Sánchez-Crespo, F.A.;

Marques da Silva, J.R.;

Gómez-Villarino, M.T.; Gallego, E.;

Fuentes, J.M.; García, A.I.; Ayuga, F.

Differential Interferometry over

Sentinel-1 TopSAR Images as a Tool for Water and Tillage Soil Erosion Analysis. Agronomy 2021, 11, 2075. https://doi.org/10.3390/agronomy 11102075

Academic Editor: Heather McNairn

Received: 1 October 2021

Accepted: 14 October 2021

Published: 17 October 2021

Publisher's Note: MDPI stays neutral with regard to jurisdictional claims in published maps and institutional affiliations.

Copyright: (c) 2021 by the authors. Licensee MDPI, Basel, Switzerland. This article is an open access article distributed under the terms and conditions of the Creative Commons Attribution (CC BY) license (https:// creativecommons.org/licenses/by/ $4.0 /)$.

\begin{abstract}
Erosion is a major problem on agricultural lands in Europe. Erosion measurement tools have traditionally been focused on delocalized quantification but without mapping the real places inside the basin where the erosion took effect. In this article, we use new space missions, such as Sentinel-1, and the opportunity they offer to obtain SAR (Synthetic Aperture Radar) images with high frequency, resolution, range, and, above all, availability to enable the application of techniques, like differential interferometry, in new fields. We propose to measure ground deformation caused by water and tillage erosion in small agricultural basins using TopSAR (Terrain Observation with Progressive Scans SAR, Synthetic Aperture Radar) images acquired by the Sentinel-1 mission, after previously verifying the accuracy of these measurements through comparison with measurements from a LIDAR (Light Detection and Ranging) system. The results of this work confirm the potential of monitoring erosion in agricultural basins with differential interferometry over Sentinel-1 TopSAR images. Its capabilities have been successfully tested in different conditions related to agricultural tasks without precipitation or storm events. This technique makes it possible to study both water and tillage erosion and sedimentation processes and even to test the efficiency of anti-erosion measures in the field or to verify the results of different management practices over time.
\end{abstract}

Keywords: erosion; Sentinel-1; SAR; interferometry

\section{Introduction}

Europe's agricultural land, both active and in disuse, is substantially affected by erosion [1-5] from two main sources: water and tillage [6,7]. Water erosion is usually observed in lower, concave slope positions following the drainage network, while tillage erosion tends to be found on higher, convex slope positions following the direction of tillage. The rate of tillage erosion may be much greater than water erosion [6,7].

Initial research into erosion measurement tools focused on delocalized quantification, such as total material lost by basins [8], but without mapping the real places inside the basin where the erosion took effect. Subsequent mathematical models based on geographical data were developed to make quantitative assessments of local erosion [9-11], but these methods still require field measurements [12-14] for calibration and commonly use data from other models to simulate rainfall $[15,16]$. Chemical soil-particle tracing of soil movement due to erosion using multispectral remote sensing data was also proposed [17] but had availability and price drawbacks. In the search for a methodology without these constraints, airborne, 
full-waveform LIDAR systems offered remote sensing data to model erosion processes but was expensive and had limited coverage and low visit frequency [18].

The Sentinel-1 mission (a joint venture between the European Space Agency and the European Commission) was an opportunity to study localized erosion by using differential interferometry through its TopSAR images, which are frequently produced and freely distributed, and have a high resolution and broad coverage [19,20]. Interferometry uses SAR images of the same area to generate interferograms in which the information is closely related to the topography of the ground [21] and can be used to represent deformation in the form of maps [22]. Differential interferometry has been used in the past to study the localized effect on the Earth's surface of natural phenomena, such as volcanic eruptions [23,24], earthquakes [25], subsidence [26], slope movements [27], landslides [28,29], and even a "jökulhlaup" (a type of glacial outburst flood) [30], as well as human-induced effects, such as coal mining [31], fracking [32], and engineering works [33,34].

The present work describes the potential of differential interferometry for water and tillage surface erosion analysis. The methodology previously developed by the authors [35] was tested in a small plot in El Molar (north of Madrid, Spain) comparing ground deformation measurements made by differential interferometry and the gold standard laser-based terrestrial LIDAR (Light Detection and Ranging) system. This work demonstrated that differential interferometry measures are sufficiently similar to LIDAR measures (for 38 out of a total 40 observations, the difference between both methods was within the range of the maximum possible error associated with the LIDAR system, and even in the remaining two, the range was only exceeded by $0.0003 \mathrm{~m}$ and $0.0049 \mathrm{~m}$ ) to make them useful in larger scale studies [36]. The methodology proposed in this work has been shown to be able to monitor spatially distributed erosion, thus enhancing the understanding of the water and tillage erosion processes involved. The results would increase the capacity for undertaking corrective or protective measures [37] since erosion and sedimentation processes could be modelled on a grid perspective at the scale of just a few square metres or days, regardless of weather or sunlight conditions $[19,38]$.

\section{Materials and Methods}

\subsection{Study Area}

The study area is a small $\left(7.05 \mathrm{~km}^{2}\right)$, monitored agricultural basin in Daganzo de Arriba, located slightly to the north of the city of Madrid, Spain, with centroid coordinates EPSG25830: 461.659; 4.494.032 (Figure 1).

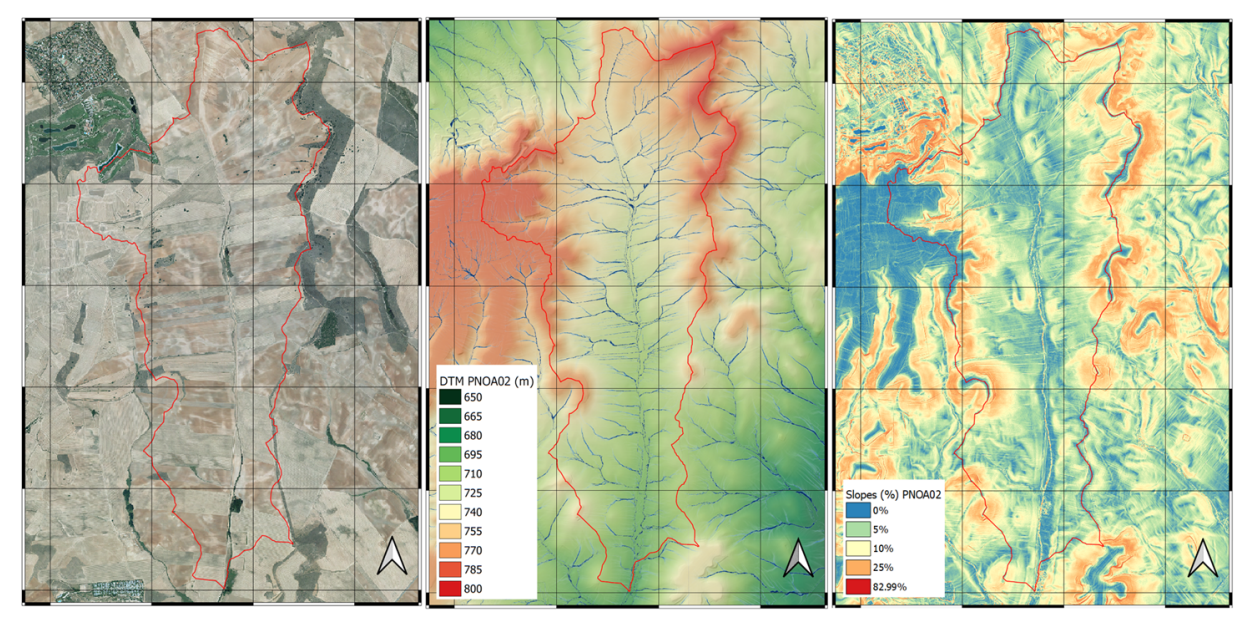

Figure 1. Monitored basin in Daganzo de Arriba. Left, aerial image from PNOA (National Plan for Aerial Orthophotography); centre, DTM; and right, slope map. Zebra frame segments of $1 \mathrm{~km}$.

It is an elongated basin with topographic heights ranging between 689.23 and $789.70 \mathrm{~m}$ above sea level. The basin has slopes of less than $10 \%$, except near the border of the 
watershed, and a main drainage network developed in the shape of a fishbone, with a secondary network heavily anthropized by the effect of agriculture, with a predominant arrangement of parallel channels following the direction of the maximum slope, EW, and WE (Figure 2).
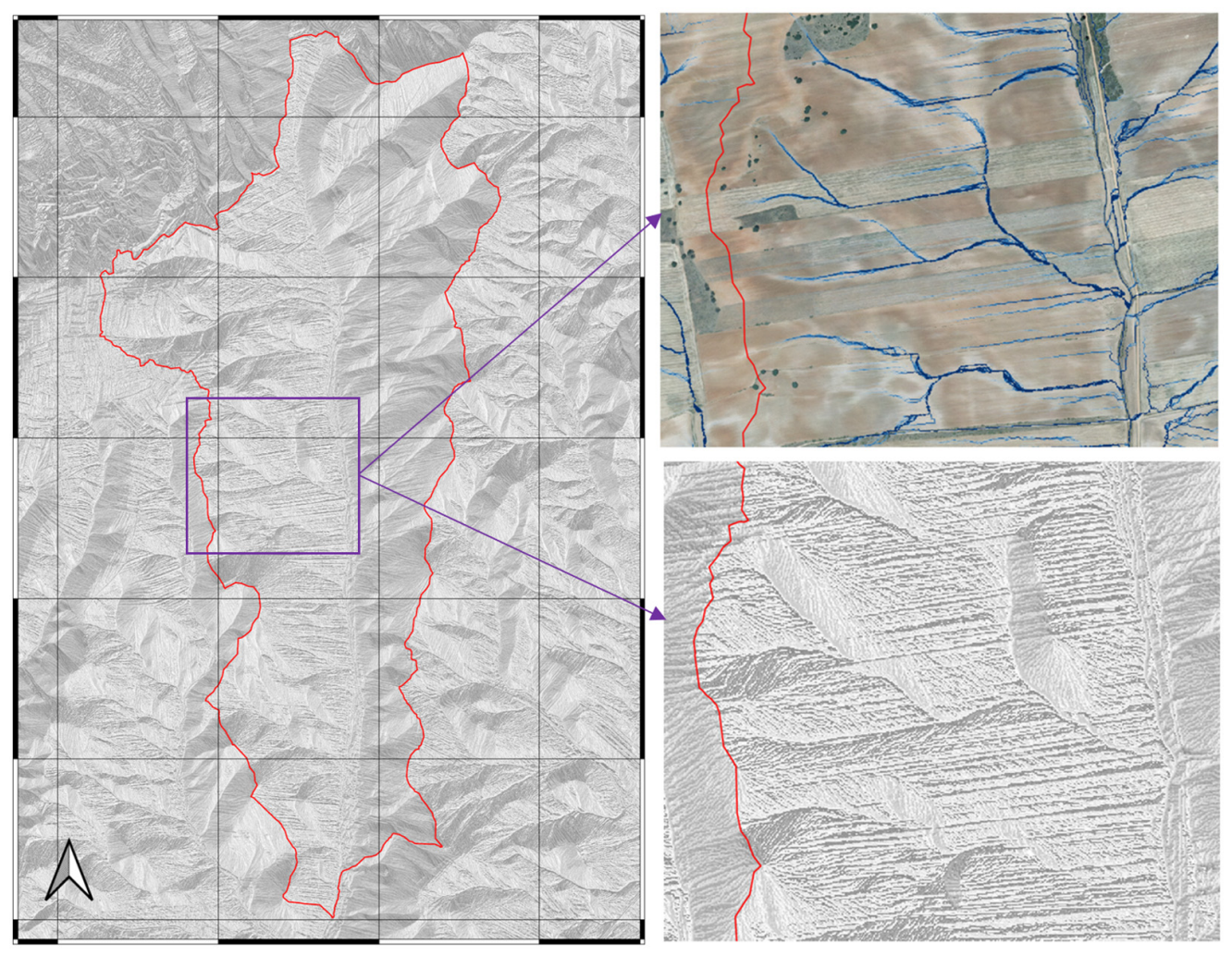

Figure 2. Monitored basin at Daganzo de Arriba from PNOA LIDAR $2 \mathrm{~m}$. Left, flow direction; top right, detail of flow accumulations; and bottom right, detail of flow directions showing the tillage according to the maximum slope. Zebra frame segments of $1 \mathrm{~km}$.

The soil coverage in the basin alternates between cereal crops and fallow land due to its agricultural use, so no interference from vegetation is expected from C-band microwave measurements [39].

\subsection{Scenarios Studied}

This study includes five scenarios: three to analyse tillage erosion and two to analyse water erosion. It should be noted that the NDVI (Normalized Difference Vegetation Index) is obtained from Sentinel-2 images whose acquisition dates are different from the Sentinel-1 images, so dates for broader periods were selected.

\subsubsection{Agricultural Tasks without Storm Events}

The influence of the agricultural tasks of tillage and harvesting on the vertical deformation measures calculated by differential interferometry over TopSAR images was studied in three different scenarios, each consisting of 12 days:

Scenario AW-1: During this period (12 days, from 15 June 2017 to 27 June 2017), there was almost no rainfall ( $3.6 \mathrm{~mm}$ in 12 days), but harvesting was carried out in multiple plots. The NDVI acquisition period was from 11 June 2017 to 1 July 2017.

Scenario AW-2: During this period (12 days, from 17 June 2019 to 29 June 2019), there was no rain, but harvesting was carried out in multiple plots. The NDVI acquisition period was from 16 June 2019 to 1 July 2019.

Scenario AW-3: During this period (12 days, from 29 June 2019 to 11 July 2019), there was almost no rainfall (less than $0.3 \mathrm{~mm}$ ), but agricultural tasks, such as tillage, were 
carried out on multiple plots. The NDVI acquisition dates were 28 June 2019 and 11 July 2019.

The moisture conditions were similar for each pair of acquisitions in the three scenarios, considering the hours of sunlight and the lack of precipitation the days before each acquisition.

\subsubsection{Significant Storm Events without Agricultural Tasks}

Free from the influence of agricultural tasks, vertical deformations caused by storms were measured by differential interferometry over TopSAR images in two different scenarios. Both scenarios include large storm events and the absence of agricultural tasks but differ in the land coverage: one is well covered with cereal crops, whereas the other has large extensions of naked soil in fallow lands.

Scenario STM-1: During this period (6 days, from 28 February 2018 to 6 March 2018), there was significant rainfall with a total of $95.1 \mathrm{~mm}$, and most plots had the protection of vegetation cover (mainly wheat and barley). Moisture conditions were quite different for both SAR acquisitions. The first acquisition came after a long period with numerous hours of sun (about $10 \mathrm{~h} /$ day) without precipitation, except the day before the acquisition, which was totally overcast and rainy, while the second acquisition occurred after seven days of precipitation and almost no insolation, and the soil was almost saturated and even waterlogged in some areas. This meant that the soil moisture at the second acquisition was much higher than at the first one, and soil moisture affects the soil-penetrating capacity of the C-band microwaves; so in this case a slight increase can be expected in elevation values in the second acquisition. The NDVI acquisition dates were 26 February 2018 and 18 March 2018.

Scenario STM-2: During this period (12 days, from 16 August 2019 to 28 August 2019), there was significant rainfall with a total of $44.4 \mathrm{~mm}$, coinciding with a large number of fallow plots, some of them recently tilled and therefore lacking the protection of vegetation cover. Moisture conditions were quite similar for each acquisition: on the first acquisition day, the soil was dry after a long period without precipitation and high insolation values, and on the second acquisition day, the soil was slightly wetter due to rain two days earlier but followed by two days of high insolation that dried the soil. The NDVI acquisition dates were 15 and 30 August 2019.

\subsection{The Sentinel-1 Mission}

The Sentinel-1 mission involves two satellites with almost polar orbits with a phase shift of $180^{\circ}$ on the same plane. These satellites are equipped with microwave C-band SAR devices, allowing image acquisition both day and night regardless of the cloud conditions $[19,38]$. Each satellite has a re-visiting frequency of 12 days, which is reduced to six days when both satellites are considered.

The sensors have four acquisition modes [38]: stripmap (SM), interferometric wide swath (IW), extra wide swath (EWS), and wave (W).

The SM mode has a high resolution $(5 \mathrm{~m} \times 5 \mathrm{~m})$ and good coverage $(80 \mathrm{~km}$ swath $)$ but very limited availability (currently only available for support for catastrophic events and for studies already under way). The EWS mode has very good coverage (400 km swath) and availability but only medium resolution $(20 \mathrm{~m} \times 40 \mathrm{~m})$. The $\mathrm{W}$ mode is a SM variation with better availability but poorer coverage. The IW mode has a medium-high resolution $(5 \mathrm{~m} \times 20 \mathrm{~m})$, good coverage (250 km swath), and very good availability. The IW mode information stream was therefore adopted for the present work.

The IW mode uses the TOPSAR (Terrain Observation with Progressive Scans SAR) technique to capture images in the form of three sub-swaths, each composed of several radar bursts [40]; this improves signal-to-noise (SNR) and distributed target ambiguity (DTAR) ratios thanks to the electronic control and synchronization of bursts and passes and produces images with less noise and fewer deformations [41]. 


\subsection{Data Acquisition}

The data used in this research consist of downloaded TopSAR images for conducting the differential interferometric analysis and data gathered on inspection visits during on-site field visits to the small basin studied in this research.

TopSAR images were downloaded from the Open Hub of the ESA (https:/ / scihub. copernicus.eu/, accessed on 16 October 2021) just a few hours after they were obtained. In order to minimize quality loss during simultaneous registration, it is important that the images in the interferogram should be taken in the same ascending or descending orbit and overlapped as much as possible.

The images used were captured by the Sentinel 1A satellite with IW mode single-look captures. The preferred polarization considered was VV, which minimizes the effect of low-growing vegetation $[42,43]$. Table 1 contains the TopSAR images used in the present work.

Table 1. The ascending orbit S-1A satellite TopSAR images used in the present work.

\begin{tabular}{c} 
TopSAR Image \\
\hline S1A_IW_SLC_1SDV_20170615T181057_20170615T181125_017048_01C665_D0FE \\
S1A_IW_SLC_1SDV_20170627T181058_20170627T181126_017223_01CBB8_D37D \\
S1A_IW_SLC_1SDV_20190617T181110_20190617T181138_027723_032115_1922 \\
S1A_IW_SLC_1SDV_20190629T181111_20190629T181139_027898_03264F_2B36 \\
S1A_IW_SLC_1SDV_20190711T181111_20190711T181139_028073_032B9D_2FF8 \\
S1A_IW_SLC_1SDV_20180228T061751_20180228T061819_020803_023AB2_8227 \\
S1A_IW_SLC_1SDV_20180306T181059_20180306T181127_020898_023D9D_F125 \\
S1A_IW_SLC_1SDV_20190816T181114_20190816T181142_028598_033C18_9BA7 \\
S1A_IW_SLC_1SDV_20190828T181114_20190828T181142_028773_034240_9BA9
\end{tabular}

Before and after each significant event studied (storm, harvesting, or tillage), a field visit was made to verify the following:

- Photography: each plot was photographed to record its condition.

- Erosion indicators, such as the presence of gullies or formerly buried stones.

- Sedimentation indicators, such as the existence of sediment accumulations.

- Vegetation coverage: on each visit, the plots were marked as fallow land, fallow land with remnants of crop harvesting, cereal crops, or forest.

- Agricultural tasks: evidence of tillage or harvesting, such as the presence of working agricultural machinery, recently tilled plots, or recently harvested crops.

- Other interferences, such as the presence of flooded areas, stacks of straw bales, grazing animals, etc.

On-site field visits were supplemented with vegetation index NDVI obtained from Sentinel 2 satellites in order to evaluate the vegetation status of each plot and any changes caused by agricultural activities [44-46]. Table 2 contains the Sentinel- 2 images used in the present work.

Table 2. The Sentinel-2 images used in the present work to calculate the NDVI.

\begin{tabular}{lc}
\hline NDVI Image & Satellite \\
\hline S2A_MSIL1C_20170611T110621_N0205_R137_T30TVK_20170611T111012 & S-2A \\
S2A_MSIL1C_20170701T111051_N0205_R137_T30TVK_20170701T111746 & S-2A \\
S2B_MSIL1C_20190616T110629_N0207_R137_T30TVK_20190616T132637 & S-2B \\
S2A_MSIL1C_20190701T110621_N0207_R137_T30TVK_20190701T113552 & S-2A \\
S2A_MSIL1C_20190628T105621_N0207_R094_T30TVK_20190628T131710 & S-2A \\
S2A_MSIL1C_20190711T110631_N0208_R137_T30TVK_20190711T131420 & S-2A \\
S2A_MSIL1C_20180226T111011_N0206_R137_T30TVK_20180226T132537 & S-2A \\
S2A_MSIL1C_20180318T110801_N0206_R137_T30TVK_20180318T132514 & S-2A \\
S2B_MSIL1C_20190815T110629_N0208_R137_T30TVK_20190815T135651 & S-2B \\
S2A_MSIL1C_20190830T110621_N0208_R137_T30TVK_20190830T113635 & S-2A \\
\hline
\end{tabular}




\subsection{Differential Interferometry}

The interferometry technique is based on accurately measuring the distance travelled by electromagnetic radiation between a SAR radar antenna and the Earth's surface and back, and the intensity and phase of the returning radiation is recorded in SAR images. By comparing two images of the same area of the Earth's surface, it is possible to make an interferogram, in which the information on the phase difference is closely related to the terrain topography, and its deformations can be graphically represented through maps.

SAR sensors accurately measure the intensity and phase of electromagnetic radiation during their journey (Figure 3), which is recorded in a SAR image by means of a twodimensional mosaic of elements named pixels, each one referring to a small area of the Earth's surface. Each pixel contains information on the intensity and phase of the reflected radiation for each cell of surface area.

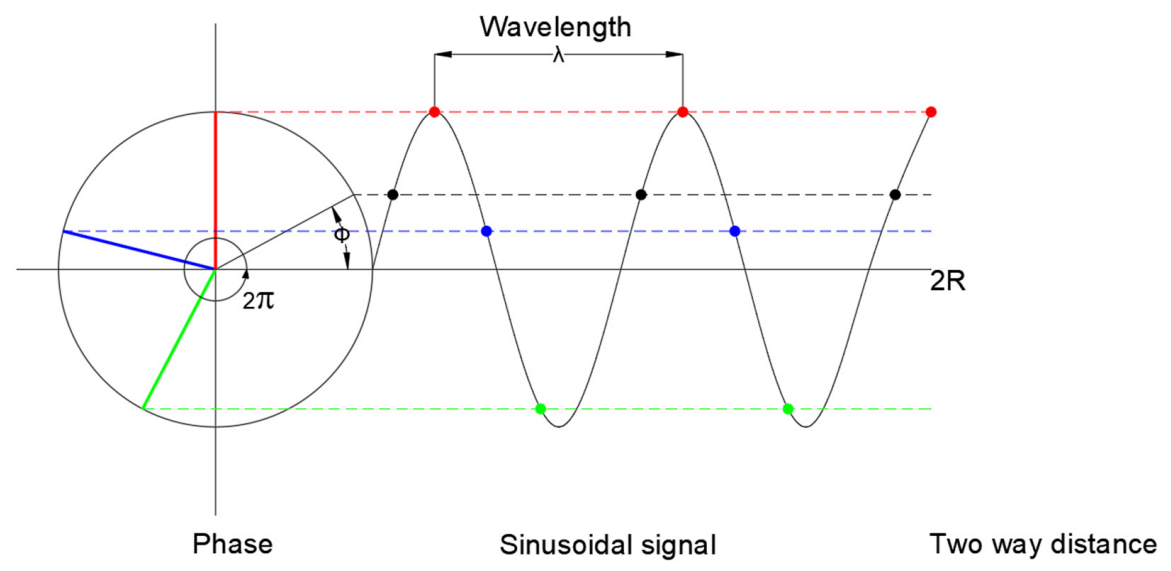

Figure 3. Phase difference. Source: ESA-TM19 InSAR Principles.

$$
\phi=\frac{2 \pi}{\lambda} 2 \mathrm{R}=\frac{4 \pi}{\lambda} \mathrm{R}
$$

According to Equation (1), the phase measurement depends on the wavelength $(\lambda)$ of the electromagnetic signal and the distance travelled (R).

SAR interferometry can determine the distance to the ground (Figure 4) by using the phase difference between two SAR observations of the same cell taken from slightly different positions [47].

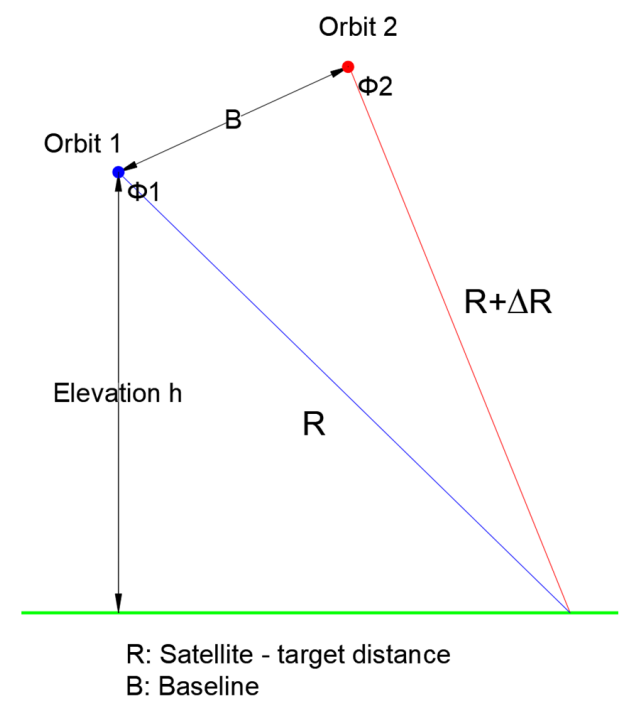

Figure 4. Satellite positions and calculation of the phase difference. Source: ESA-TOPS Interferometry Tutorial. 


$$
\begin{gathered}
\phi_{1}=\frac{4 \pi}{\lambda} \mathrm{R} \\
\phi_{2}=\frac{4 \pi}{\lambda}(\mathrm{R}+\Delta \mathrm{R}) \\
\Delta \phi=\phi_{2}-\phi_{1}=\frac{4 \pi \Delta \mathrm{R}}{\lambda}
\end{gathered}
$$

According to Equations (2)-(4), the phase difference between two acquisitions depends on the wavelength $(\lambda)$ of the electromagnetic signal used and the difference between the distances that the signal travelled in each acquisition $(\Delta R)$.

SAR interferometry requires the acquisition of both images and the subsequent construction of an interferogram by combining the phase differences, whose information is closely related to the topography of the terrain [21] and allows the mapping of surface deformations.

According to previous research [47], the phase difference obtained can be caused by five factors (Equation (5)).

$$
\Delta \varphi=\Delta \varphi_{\text {flat }}+\Delta \varphi_{\text {elevation }}+\Delta \varphi_{\text {displacement }}+\Delta \varphi_{\text {atmosphere }}+\Delta \varphi_{\text {noise }}
$$

where:

flat $=$ the curvature of the Earth elevation = topography

displacement $=$ deformations of the terrain between the two information acquisitions atmosphere $=$ differences in relative humidity, pressure, and temperature between information acquisitions noise $=$ changes over time in volume scattering and acquisition angles, etc.

The interferometric process removes all these factors except those of interest: elevation (to generate digital models of the terrain) and displacement (to analyse surface changes). Therefore, if the difference in phase caused by the topography is removed from the interferogram, the resulting difference corresponds only to surface deformations between the acquisition dates.

A coherence band is obtained along with the difference phase band and is calculated within the interferogram to estimate the similarity between both images at a pixel scale between 0 (no similarity) and 1 (total similarity). According to previous researches [48,49], the coherence loss between a pair of images can be explained through Equation (6).

$$
\gamma=\gamma_{T} * \gamma_{G} * \gamma_{V} * \gamma_{P}
$$

where:

$\gamma_{T}=$ Temporal factor: cannot be avoided and is due to differences on the ground occurring between two information acquisitions; this is the object of the present work.

$\gamma_{G}=$ Geometric factor: caused by errors in the orbits followed by satellites; can be partially removed from calculations.

$\gamma_{V}=$ Volumetric factor: the presence of vegetation causes the appearance of the volumetric factor, which cannot be removed.

$\gamma_{P}=$ Processing factor: caused by calculation errors, which must be minimized and avoided at all costs.

\subsection{Software}

The ESA's Sentinel Application Platform (SNAP) was used for the differential interferometric analysis of pairs of TopSAR images [50,51], applying the SNAPHU algorithm (Copyright 2002-2020 Board of Trustees, Leland Stanford Jr. University) produced at Stanford University for the unwrapping phase [52-54] inside a CYGWIN (Copyright ( C) Cygwin authors) environment (a collection of tools which provide functionality like a Linux dis- 
tribution on Windows). The ESA's Sentinel application platform (SNAP) was also used to calculate the NDVI index, and the differences in the NDVI index between days were computed with QGIS software.

\subsection{Interferometry Calculation Steps}

To build the interferograms, interferometric pairs of SAR images were coregistered, aligning the images at the pixel level and using the older one as the image reference. This coregistration was done using 21-point Bisinc interpolation, enhanced spectral display, and orbital correction (with the Sentinel Precise polynomial degree 3 option) [55].

Once the images were aligned, their interferograms (intensity bands, phase, and coherence) were calculated and corrected by considering the Earth's curvature (using a fifth-degree polynomial) and performing an interpolation of the capturing satellite's orbit (using a third-degree polynomial).

One peculiarity of TopSAR images is that they are acquired by radar bursts [41], so the spaces between the bursts were eliminated to advance the interferometric analysis [40]. The image was then cropped to the study area, which drastically reduces the time required for the subsequent operations.

After obtaining the interferogram, the dephasing due to the topography was eliminated using an SRTM 1sec HGT digital terrain model. Then, after reducing the noise effect by Goldstein phase filtering [56], the resulting phase difference corresponds to the deformation and atmosphere differences occurring between data acquisitions [21]. The coherence band was obtained along with the difference phase band, and its information is used in the final step to make a vertical adjustments to the deformation raster to compensate, at least partially, for the atmosphere factor.

The interferograms were unwrapped with the SNAPHU algorithm in order to calculate the vertical displacements [52-54].

The vertical displacement in each pixel was calculated using Equation (7) [57].

$$
d=-\frac{\lambda}{4 \pi \cos \theta_{i n c}} \Delta \phi_{d}
$$

where:

$d=$ the deformation according to the vertical axis

$\lambda=$ the wavelength used

$\Delta \phi_{d}=$ the phase displacement for each cell between data acquisitions

$\theta_{\text {inc }}=$ incident angle

Differential interferometry can obtain deformation only in the direction of line of sight (LOS), so vertical deformation is estimated as a vertical projection of the LOS in the vertical direction [58].

The terrain was geometrically corrected to compensate for the distortions in the SAR image due to variations in the terrain with respect to the inclination of the sensor. The aim was to produce a two-dimensional representation that faithfully reflected the realworld situation. This was done using a Range-Doppler orthorectification method [59] to geodecodify the SAR images, considering information for the capturing satellite's orbit, time records, conversion factors for the oblique distance to the Earth's surface, and a reference digital terrain model to determine the exact location represented by each pixel.

This geometric correction was done using the ETRS89 projection system, which produced two raster products: the terrain deformation between data acquisitions and the coherence between the acquisitions.

Finally, the coherence band was used to make a vertical adjustment required to compensate vertical error in the estimation of local deformations. As the flatness, noise, and elevation factors were previously removed, the remaining errors were due to atmosphere factor [47]. Representative cells with very high coherence, hence with little likelihood of being deformed, were chosen to provide the zero-deformation reference. The value of its twin cells in the deformation raster were then used to create an adjustment raster by 
interpolating its values $[30,36,60]$. Finally, the adjustment raster was subtracted from the deformation raster to obtain the adjusted deformation raster.

\subsection{Normalized Difference Vegetation Index}

The data for the calculation of the NDVI were obtained from the ESA's Sentinel-2 satellite platform. It is important to note that the satellite overpass calendar for Sentinel-2 is different from Sentinel-1, which is the reason the NDVI and interferometry dates do not match exactly. Sentinel-2 is also weather dependent, so images collected on cloudy days were rejected.

If the exact date of the Sentinel-1 overpass was not available, another date was selected in order to cover a longer period, seeking an earlier date for the first acquisition in the interferogram pair and a subsequent date for the second one.

The NDVI algorithm shows the strength and vitality of the vegetation on the Earth's surface [44-46,61,62] and is obtained through Equation (8) by using the reflection in the near-infrared spectrum (NIR) obtained by Sentinel-2 band B8 (842 nm) and the reflection in the red range of the spectrum $(R E D)$ obtained by Sentinel-2 band B4 (665 nm)

$$
N D V I=\frac{N I R-R E D}{N I R+R E D}
$$

The difference in the NDVI index between two days is calculated by simply subtracting the raster values of the second day from the raster values of the first day using QGIS software. The NDVI index has values between -1.0 and 1.0 [44-46,63], with negative values corresponding to water or snow areas.

The following classification was made by comparing the NDVI values obtained from ESA's Sentinel-2 with the state of the vegetation coverage at the time of the acquisitions in the plots in the basin:

Values from 0.0 to 0.1 : Fallow lands, bare soils, or urban areas.

Values from 0.1 to 0.2 : Fallow lands with crop remnants.

Values from 0.2 to 0.4 : Cereal crops at different stages.

Values above 0.4: Forest areas.

\section{Results}

\subsection{Agricultural Tasks without Storm Events}

In NDVI acquisition (Figure 5a,b), areas shaded yellow and light green represent ripe cereal crops ready to harvest, while red and orange represent fallow land. Plots that change from yellow-green (Figure 5a) to red-orange (Figure 5b) indicate plots that were harvested between both acquisition dates. Figure $5 c$ shows the variation in the NDVI between the acquisition dates, where green denotes crop growth, orange-red represents harvesting tasks, and yellow and yellow-orange represent no change or crop ripening.

As can be seen from the NDVI variations (Figure 5), harvesting was carried out in multiple plots in scenarios AW-1 and AW-2 (verified during field inspection).

Tillage was observed in scenario AW-3 but no harvesting. As tillage has no effect on the NDVI index, it shows no changes.

Coherence values between acquisitions in scenarios AW-1 and AW-2 are relatively high (Figure 6), with a mean value of 0.635 (AW-1) and 0.695 (AW-2), a standard deviation of $0.153(\mathrm{AW}-1)$ and $0.167(\mathrm{AW}-2)$ and a maximum of $0.948(\mathrm{AW}-1)$ and $0.976(\mathrm{AW}-2)$. As can be observed in the coherence histogram (Figure 6), most values are within a range of 0.5 to 0.85 for $\mathrm{AW}-1$ and $0.55-0.90$ for $\mathrm{AW}-2$.

Coherence values in scenario AW-3 (Figure 6) were somewhat poorer than in previous scenarios owing to the agricultural tasks (mainly tillage) that affected the surface of the land (plots with a dominance of orange and red). Fallow land without tillage had better coherence values, as seen in plots where green and blue are the main colours. The basin in scenario AW-3 had a mean coherence value of 0.459 , a standard deviation of 0.206 , and a maximum of 0.930 . This large variation in values is because there are two different groups: 
high coherence values correspond to non-tilled plots, and low coherence values correspond to tilled plots. This divergence produces a greater standard deviation and a wider range of values, from 0.2 to 0.7 (Figure 6).

a.-NDVI 11/06/2017

b.-NDVI $01 / 07 / 2017$

c.-Difference

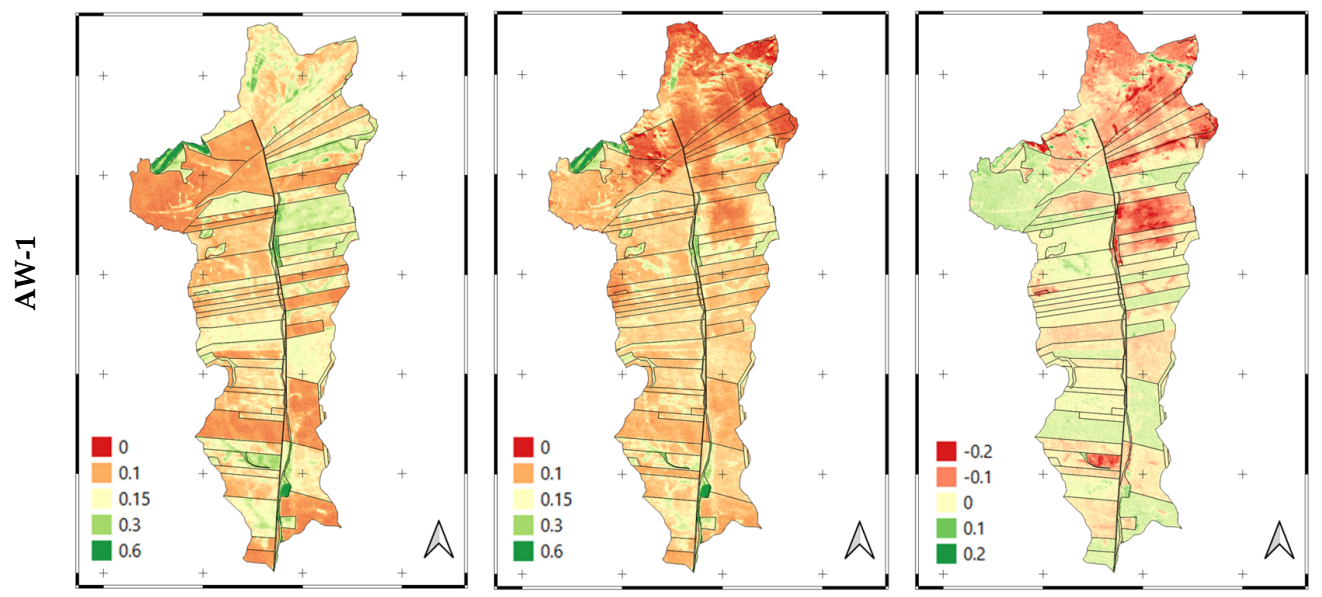

a.-NDVI 16/06/2019

b.-NDVI 01/07/2019

c.-Difference
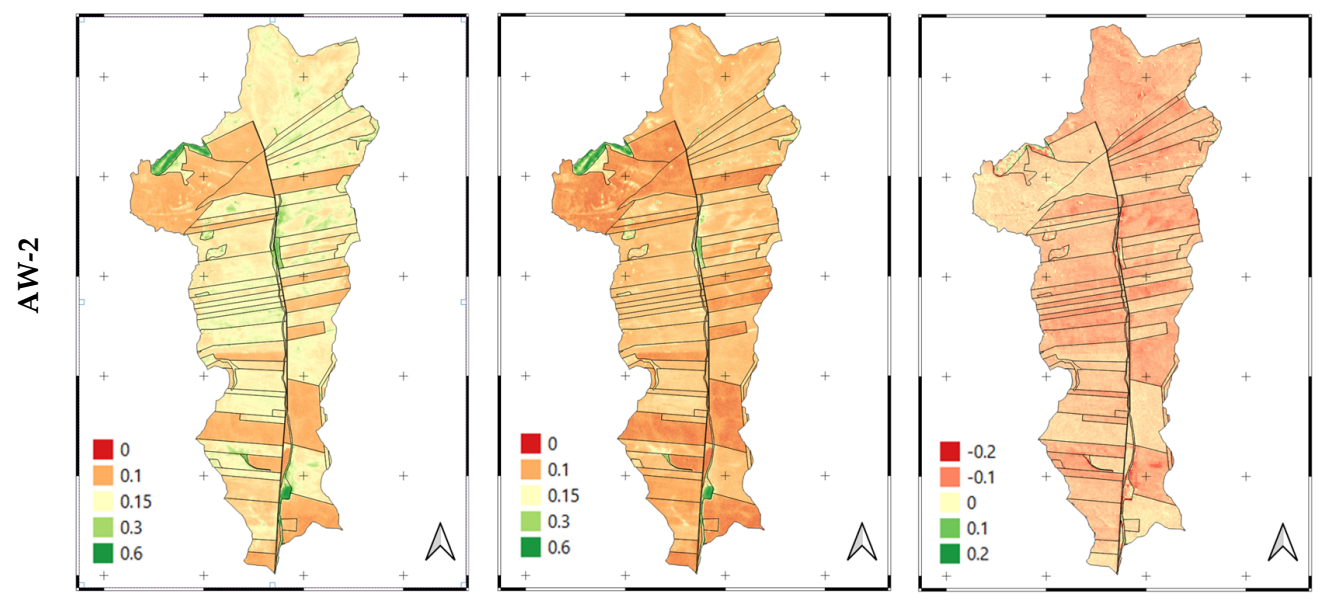

a.-NDVI 28/06/2019

b.-NDVI $11 / 07 / 2019$

c.-Difference
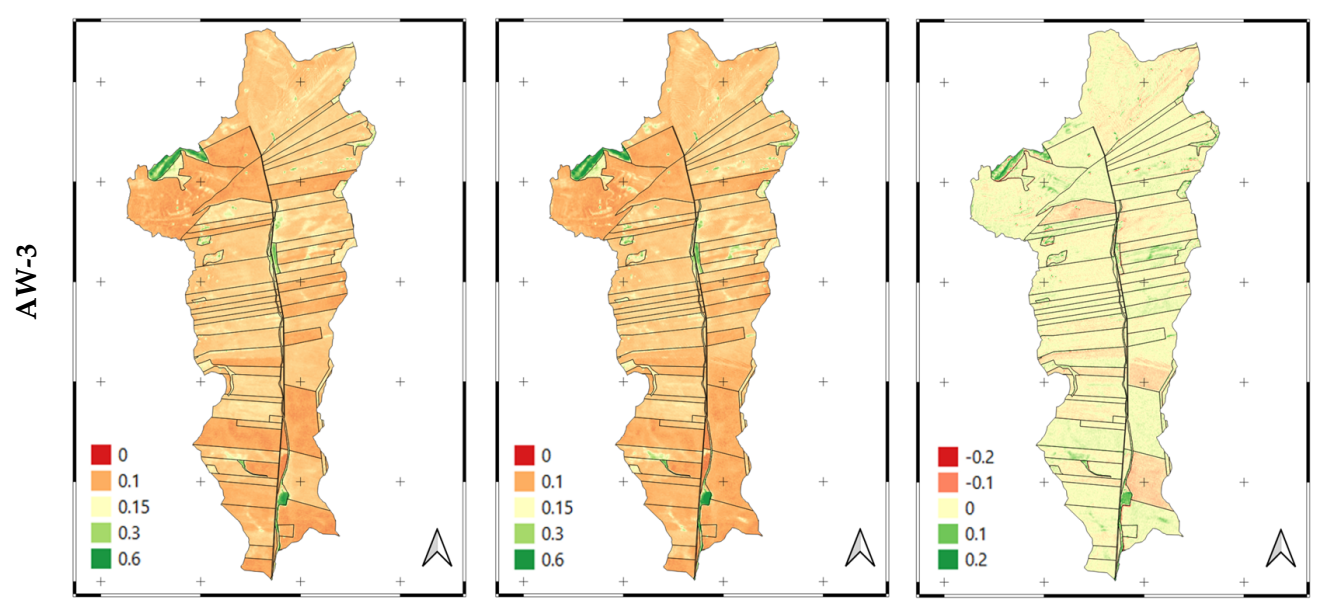

Figure 5. NDVI at the beginning/end of AW-1, AW-2, and AW-3 (a,b) and variation (c). Zebra frame segments of $1 \mathrm{~km}$. 

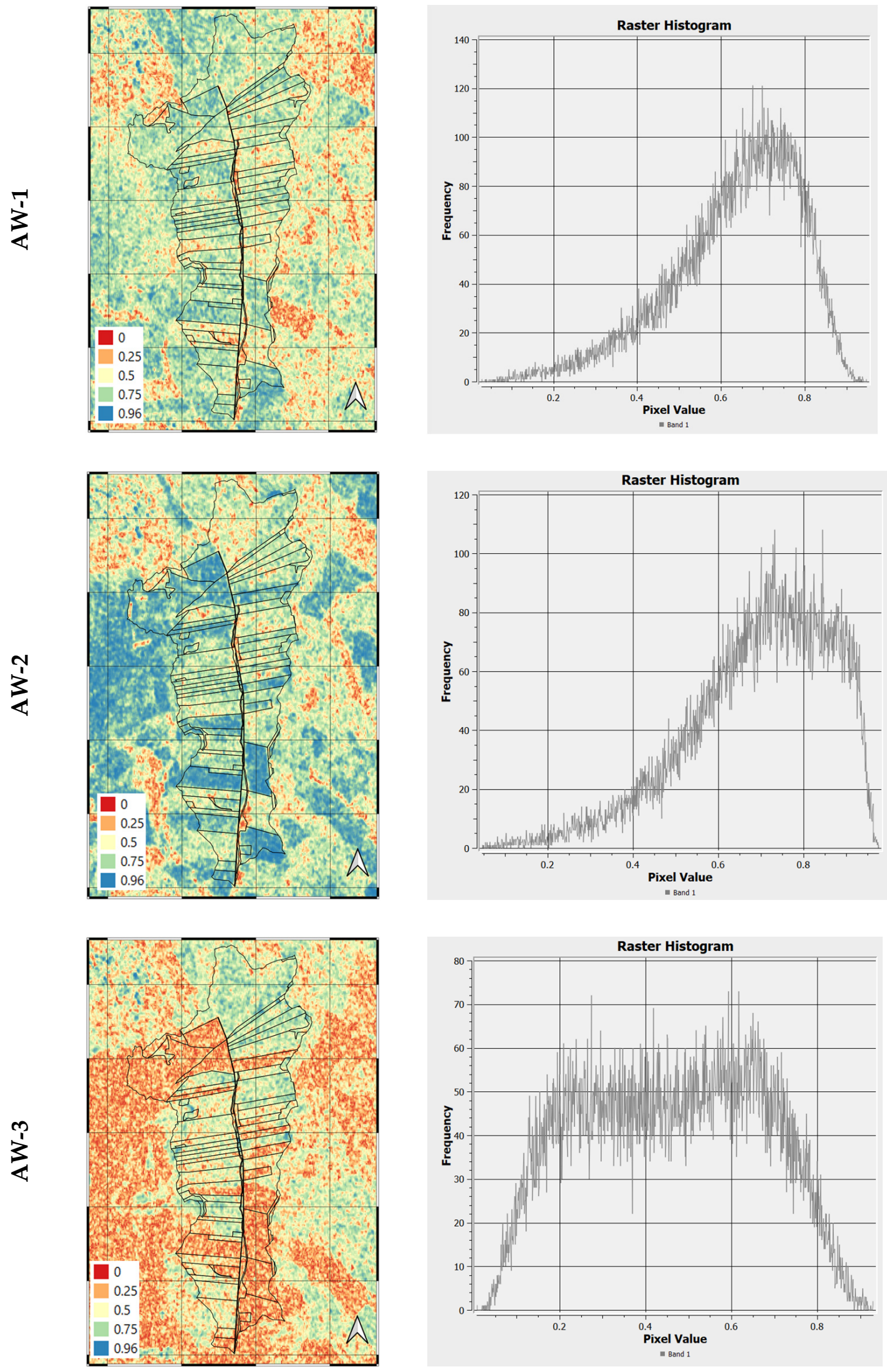

Figure 6. Coherence raster between acquisitions in scenarios AW-1, AW-2 and AW-3. The histogram shows only values of the part of the raster inside the basin. Zebra frame segments of $1 \mathrm{~km}$. 
High coherence (value $>0.95$ ) points were selected for each scenario both inside and around the basin, and their matching deformation values were used to calculate the vertical adjustment raster by means of interpolation (Figure 7) to compensate for noise and atmospheric artifacts. The correction raster was subtracted from the deformation raster to obtain the corrected deformation raster for each scenario (Figure 8).

莡

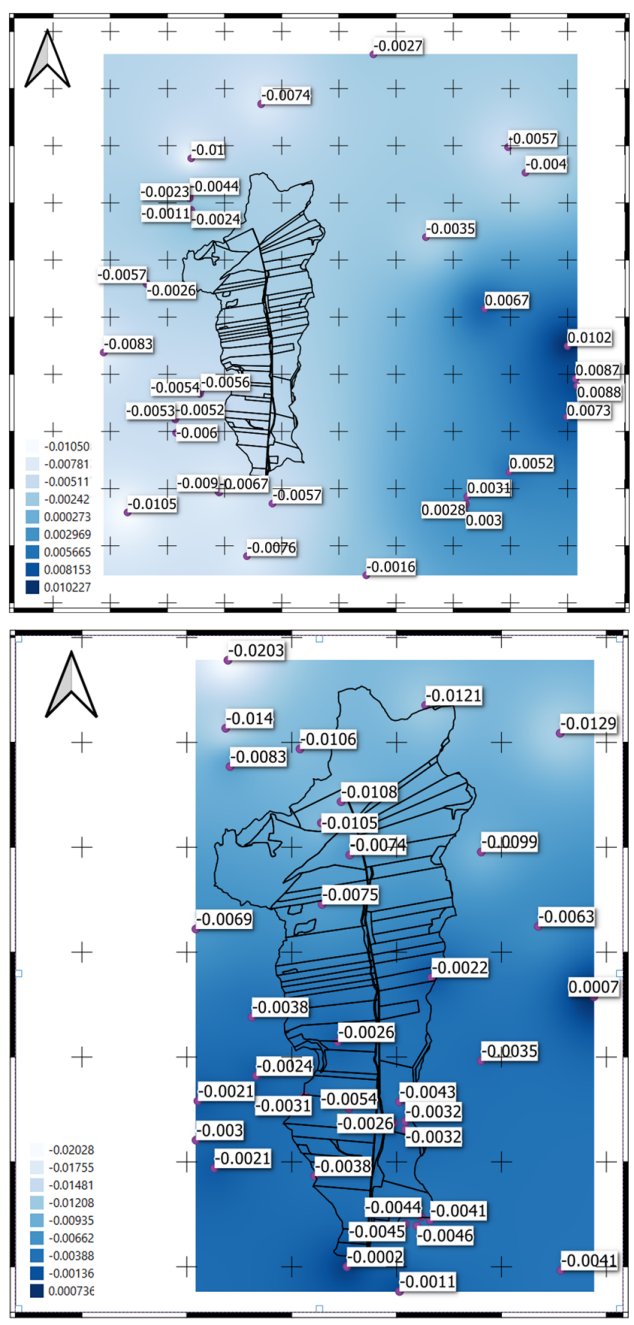

㢳

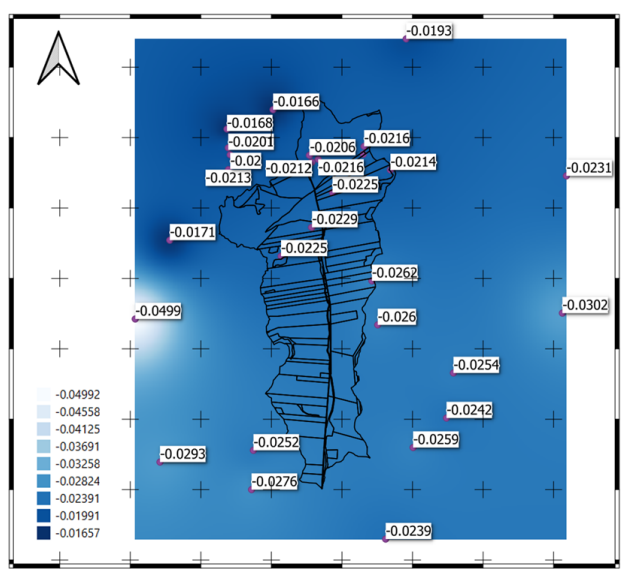

Figure 7. Matching deformation values to high-coherence points and its interpolation. Zebra frame segments of $1 \mathrm{~km}$. 

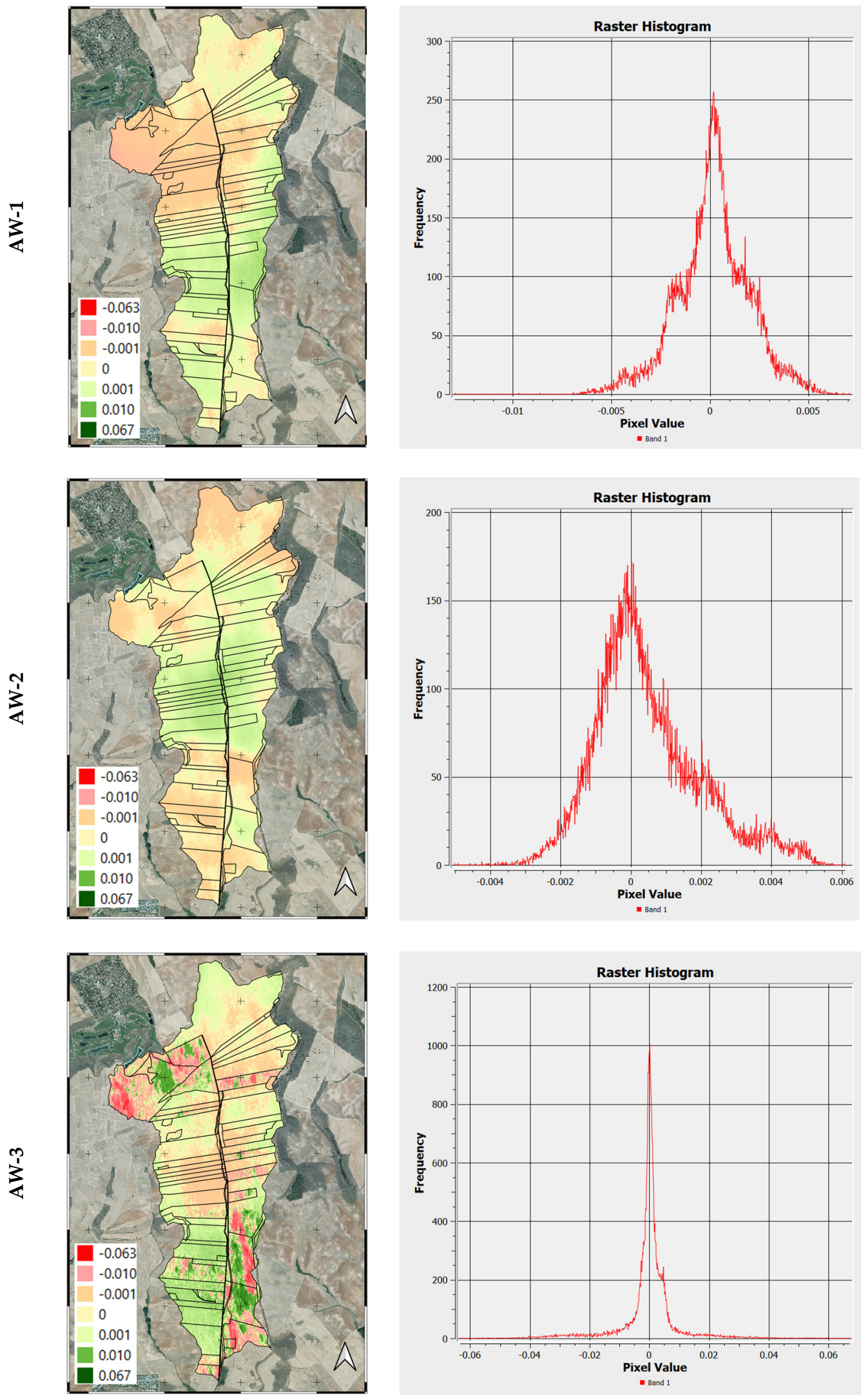

Figure 8. Corrected deformation raster in metres (m) for scenario AW-1 (15-27 June 2017), AW-2 (17-29 June 2019), and AW-3 (29 June-11 July 2019) and their histograms. Zebra frame segments of $1 \mathrm{~km}$. 
The corrected deformation raster for scenarios AW-1, AW-2, and AW3 and its histogram (Figure 8) show the following:

- In harvesting scenarios (AW-1 and AW-2), no deformation differences are found between harvested and non-harvested plots.

- In the tillage scenario (AW-3), no deformation is observed (mainly in yellow) in nontilled plots, while a mix of positive (green) and negative (red) deformations of the Earth's surface is observed in tilled plots.

Table 3 shows the total deformation range inside the basin-that is, the difference between the maximum positive and negative deformations-and the mean deformations inside the basin (with the standard deviation) for scenarios AW-1 to AW-3.

Table 3. Global deformation results of scenarios AW-1 to AW-3.

\begin{tabular}{cccccc}
\hline \multirow{2}{*}{ Scenario } & \multicolumn{5}{c}{ Deformation } \\
\cline { 2 - 6 } & $\begin{array}{c}\text { Max. Negat. } \\
\text { Value (m) }\end{array}$ & $\begin{array}{c}\text { Max. Posit. } \\
\text { Value (m) }\end{array}$ & Range (m) & Mean (m) & $\begin{array}{c}\text { Standard } \\
\text { Deviation (m) }\end{array}$ \\
\hline AW-1 & -0.01295 & 0.00711 & 0.02001 & 0.00016 & 0.0018 \\
\hline AW-2 & -0.00503 & 0.00610 & 0.0111 & 0.00047 & 0.0015 \\
\hline AW-3 & -0.06328 & 0.06696 & 0.1302 & 0.00021 & 0.0087 \\
\hline
\end{tabular}

In the periods 15-27 June 2017 (AW-1) and 17-29 June 2019 (AW-2), there was almost no rainfall and no tillage (only harvesting), so no erosion should be observed. The main deformation values for both periods $(0.00016$ and $0.00047 \mathrm{~m})$ and the small deformation ranges $(0.0200$ and $0.0111 \mathrm{~m})$ confirm the absence of erosion and sedimentation processes. However, during this period, there were major changes in the height of cereal crops (harvesting tasks) that were not detected as deformation by differential interferometry over C-Band microwaves of TopSAR images and thus were not reflected in the deformation raster.

There was no rainfall during the period in scenario AW-3 (29 June 2019 to 11 July 2019), but there were tillage works in several plots. As expected, there was no basin level erosion, as could be verified from the mean value of the basin deformation that tended to zero $(0.00021 \mathrm{~m})$, although high local deformation values were detected inside the plots with tillage works performed during scenario AW-3, ranging from $-6.3 \mathrm{~cm}$ to $+6.7 \mathrm{~cm}$. These local deformation values correspond to tillage erosion and sedimentation processes limited to the interior of each plot (Figure $8 \mathrm{AW}-3$ ).

\subsection{Significant Storm Events without Agricultural Tasks}

NDVI STM-1: As can be seen in Figure 9c, NDVI differences were positive (green) according to the vegetation growth and absence of harvesting, except for two plots to the south and one plot to the north. Figure $9 \mathrm{a}, \mathrm{b}$ both show a large number of plots with a predominance of green shades, implying that they had a cereal crop coverage. Some plots show a predominance of orange or yellow shades, so they lack vegetation coverage, as these are fallow lands with bare soil or with the remnants of crop harvesting.

NDVI STM-2: Figure 9a,b both show most plots with predominance of orange, indicating a lack of vegetation coverage, and are fallow lands with bare soil or with the remnants of crop harvesting. Only a few plots are green, implying that they had some vegetation coverage. These plots are also green in Figure 9c, where crops are still growing. The field visit confirmed that the coverage of these green NDVI plots in Figure 9c were weeds growing between the remnants of the harvested cereal crops. The rest of the plots are coloured yellow in the image on the right, so they remained fallow during the study period. 


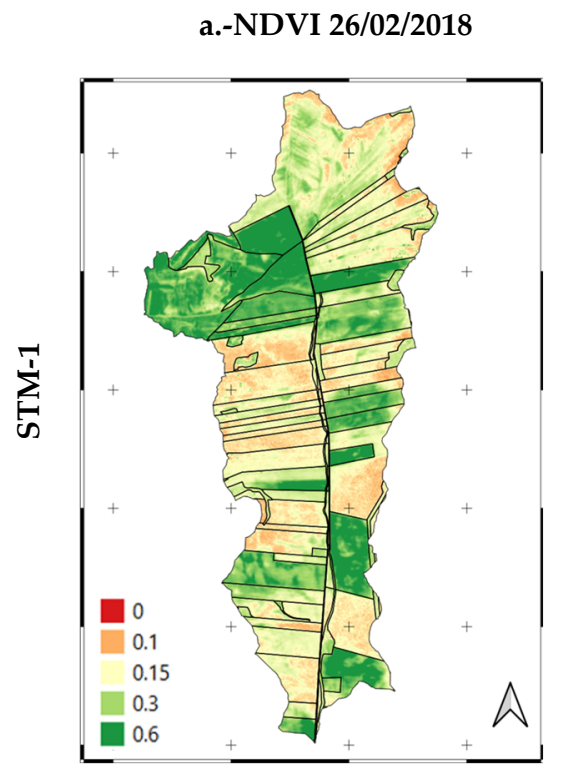

a.-NDVI 15/08/2019
b.-NDVI 18/03/2018

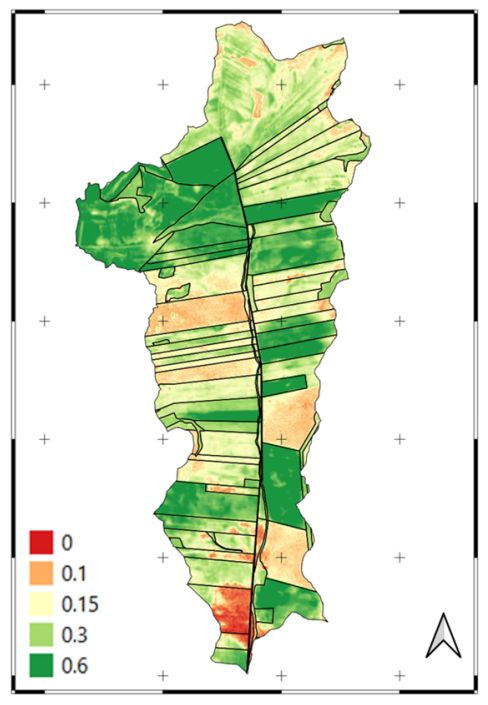

b.-NDVI 30/08/2019
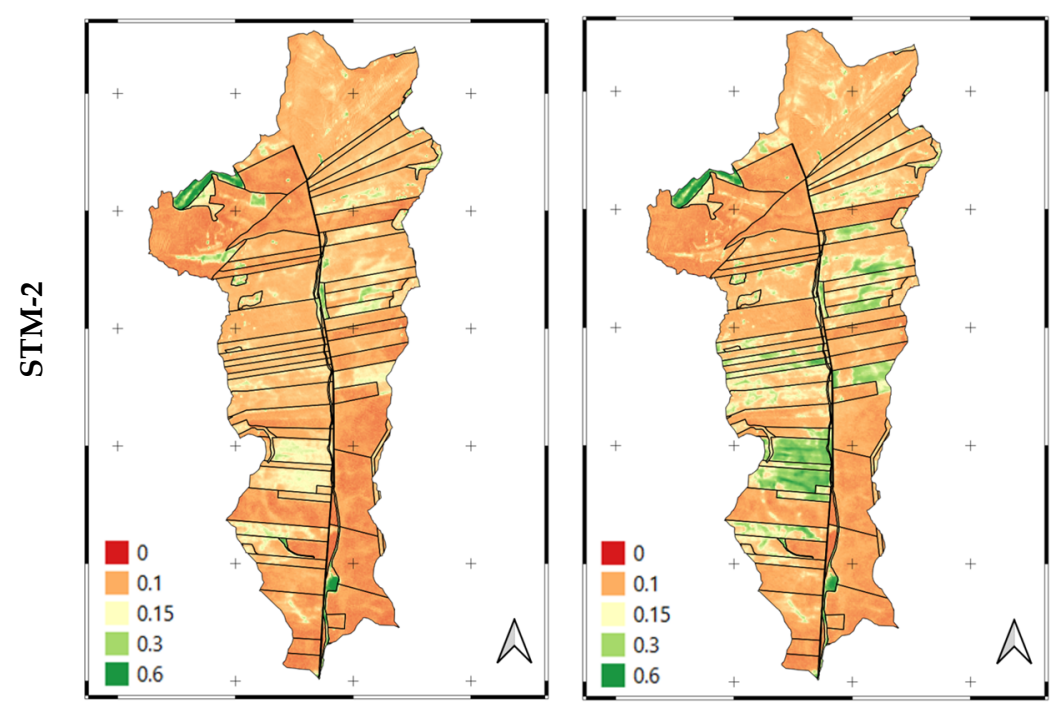

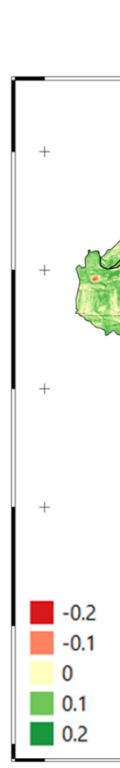

c.-Difference

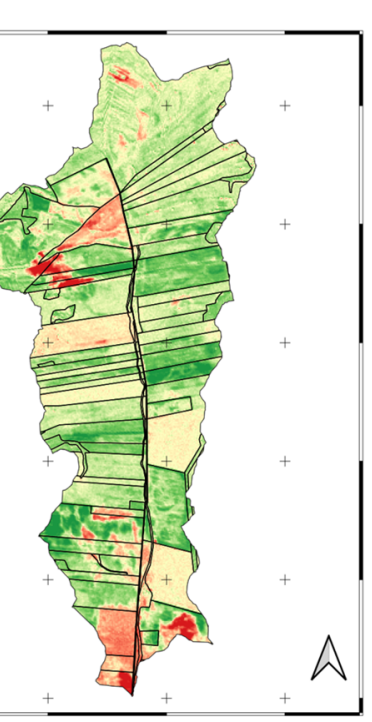

c.-Difference

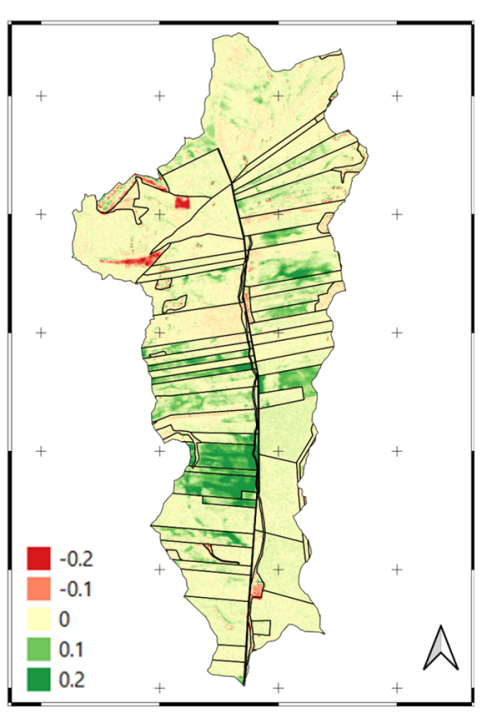

Figure 9. NDVI at the beginning and end of AW-1, 2, and $3(\mathbf{a}, \mathbf{b})$ and NDVI variation (c). Zebra frame segments of $1 \mathrm{~km}$.

Owing to the erosion expected due to the heavy rainfall, the coherence values of both scenarios STM-1 and STM-2 (Figure 10) were low, as erosion corresponds to the temporal factor, an unavoidable component of coherence loss.

A different coherence behaviour is observed between plots with and without vegetal coverage in scenario STM-1. As can be seen, the greener areas in Figure 9a,b (higher NDVI index and more developed vegetation coverage) correspond to the highest coherence values in Figure 10, while the red-orange areas in Figure 9a,b (lower NDVI index, fallow land) correspond to the lowest coherence values in Figure 10. The basin in scenario STM-1 had a mean coherence value of 0.437 , a standard deviation of 0.174 , and a maximum of 0.950 . 

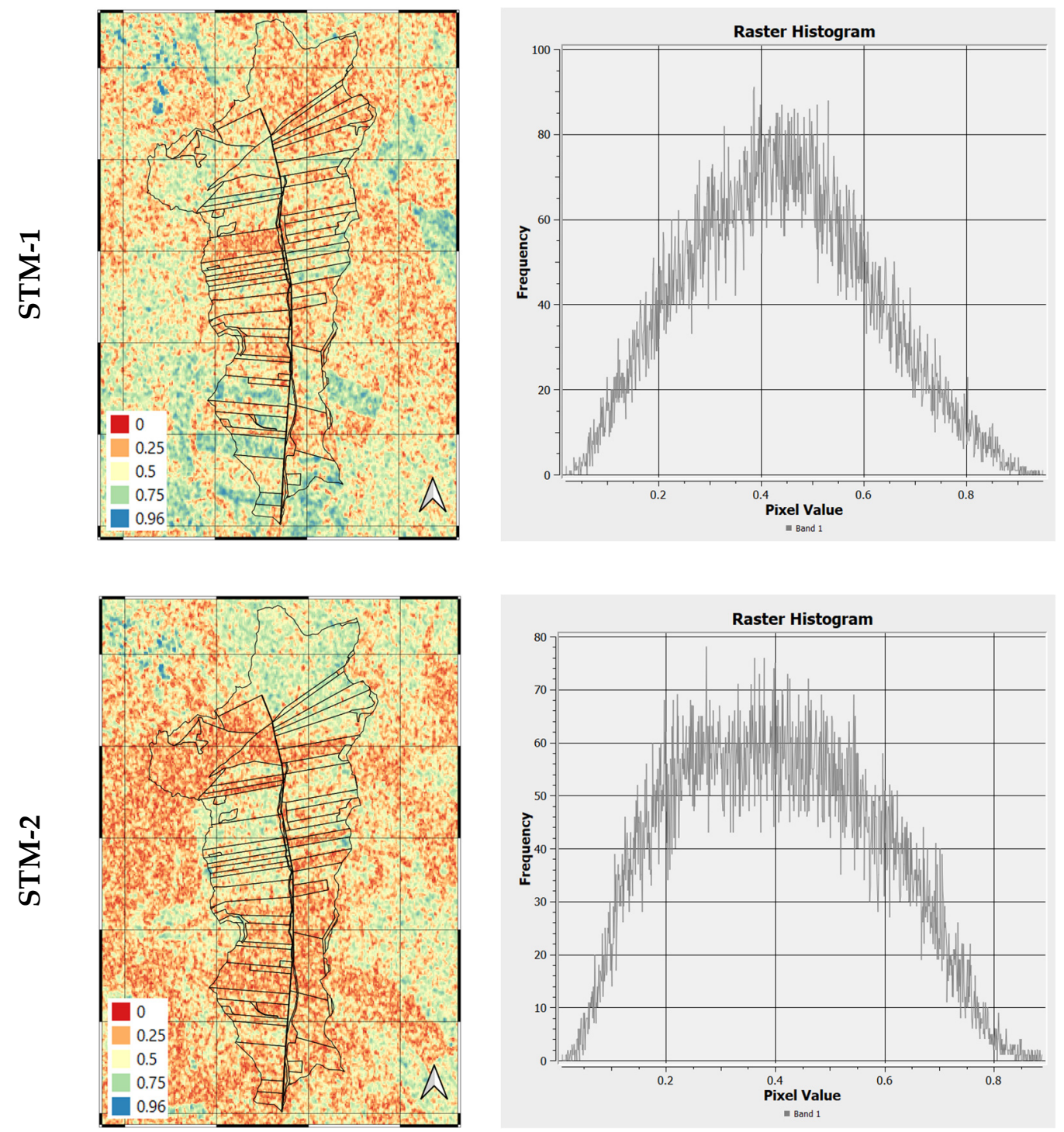

Figure 10. Coherence raster between acquisitions in scenarios STM-1 and STM-2. The histogram shows only values of the part of the raster inside the basin. Zebra frame segments of $1 \mathrm{~km}$.

A different coherence behaviour (Figure 10) is observed in scenario STM-2 between plots with a similar low NDVI value corresponding to fallow land (Figure 9a,b), so these plots should have a similar lack of vegetation coverage. However, two kinds of fallow land were registered on field visits: recently tilled fallow land with bare soil (see the agricultural tillage tasks detected in scenario AW-3, agricultural tasks without storm events, from 29 June 2019 to 11 July 2019), with low coherence values (predominance of red-orange), and fallow land without tillage and with remnants of crop harvesting, with higher coherence values (predominance of yellow-green). The basin in scenario STM-2 had a mean coherence value of 0.401 , a standard deviation of 0.178 , and a maximum of 0.889 .

Both scenarios showed fewer high-coherence (value $>0.95$ ) points for selection than in the periods without heavy rain but enough to interpolate the vertical adjustment raster (Figure 11). 


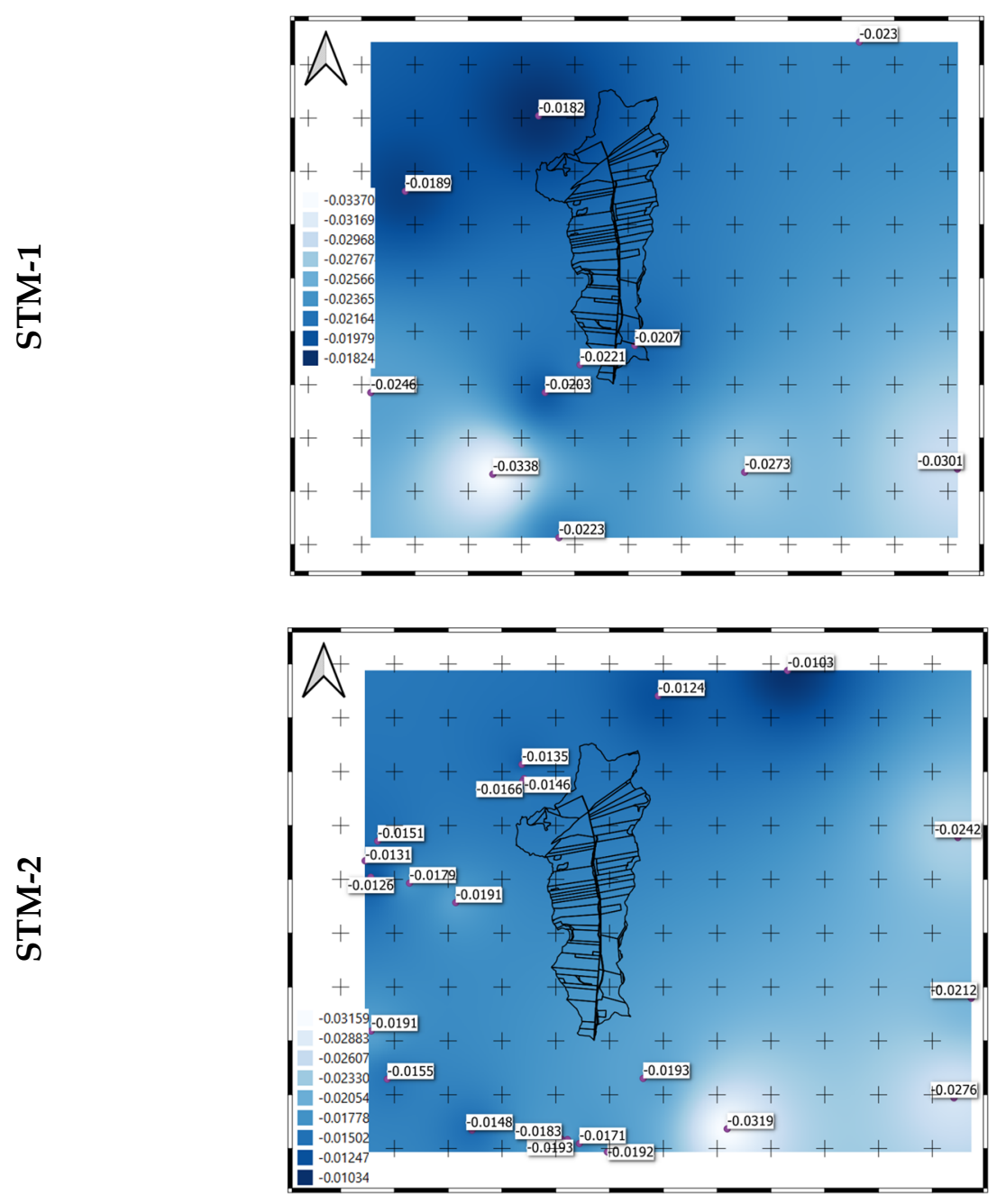

Figure 11. Matching deformation values to high-coherence points and its interpolation. zebra frame segments of $1 \mathrm{~km}$.

The corrected deformation raster is obtained for each scenario after subtracting the correction raster from the deformation raster (Figure 12). Table 4 shows the total deformation range and the mean deformations inside the basin (with the standard deviation) for scenarios STM-1 and STM-2.

Table 4. Global deformation results of scenarios STM-1 and STM-2.

\begin{tabular}{cccccc}
\hline \multirow{2}{*}{ Scenario } & \multicolumn{5}{c}{ Deformation } \\
\cline { 2 - 6 } & $\begin{array}{c}\text { Max. Negat. } \\
\text { Value (m) }\end{array}$ & $\begin{array}{c}\text { Max. Posit. } \\
\text { Value (m) }\end{array}$ & Range (m) & Mean (m) & $\begin{array}{c}\text { Standard } \\
\text { Deviation (m) }\end{array}$ \\
\hline SM-1 & -0.04032 & 0.04349 & 0.08380 & 0.0000936 & 0.00460 \\
SM-2 & -0.06218 & 0.04867 & 0.11085 & -0.0027990 & 0.00608 \\
\hline
\end{tabular}

From the comparison between the deformation raster for scenario STM-1 (Figure 12, STM-1) and the information collected in field visits:

- Dark green areas: visual inspection of the basin showed that in this case, dark green areas corresponded to sediment $(\max .4 .4 \mathrm{~cm}$ ) and flooded areas (Images 2-3 in Figure 13).

- Light green areas: this area requires interpretation. There are extensive light green areas that cannot correspond to sedimentation areas (Image 4 in Figure 13). It is likely 
that the slight elevation recorded is due to clay expansion phenomena or changes in the dielectric constant of the soil that cause a more superficial rebound of the C-band microwaves rather than sediment phenomena.

- Yellow areas: no erosion, mainly plots with a coverage of cereal crops.

- Orange to red areas: areas with moderate to high erosion (max. $4.03 \mathrm{~cm}$ ), forming even rills and gullies in the reddest areas, as observed in the field. Mainly fallow lands without vegetation coverage (Image 1 in Figure 13).
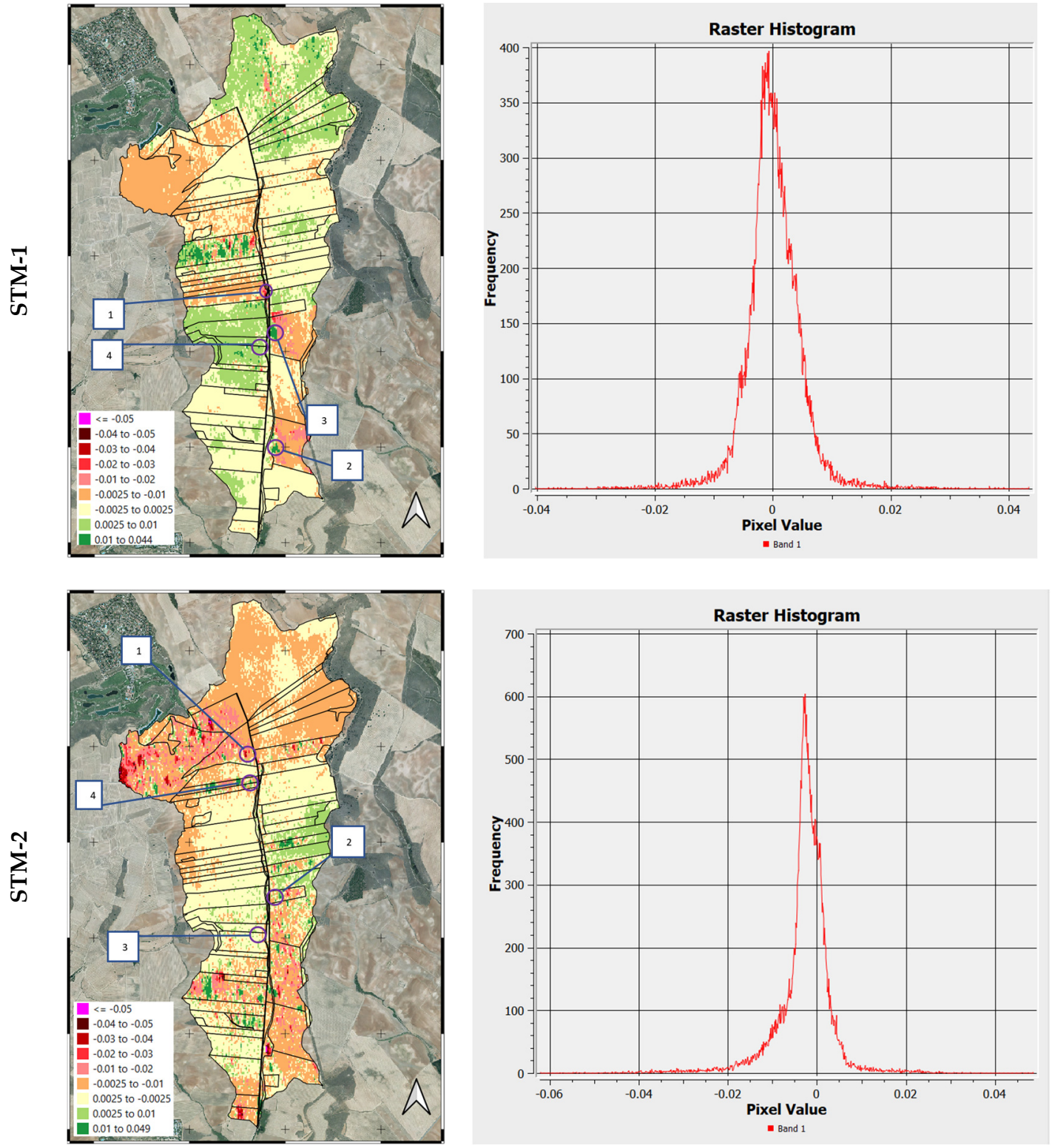

Figure 12. Corrected deformation raster in metres (m) between 28 February-6 March 2018 (STM-1), 16-28 August 2019 (STM-2), and their histogram. Callouts marks in the picture on the left are explained in Figure 13 (STM-1) and Figure 14 (STM-2). Zebra frame segments of $1 \mathrm{~km}$.

From the comparison between the STM-2 corrected deformation raster (Figure 12) and the information collected on field visits:

- Dark green areas: visual inspection of the basin showed that in this case, the dark green areas correspond to sediment areas with a maximum of $4.87 \mathrm{~cm}$ (Image 2 in Figure 14). 
- Yellow areas: no erosion, mainly fallow land with remnants of harvested cereal crops (Image 3 and the right part of Image 4 in Figure 14).

- $\quad$ Red and orange areas: areas with moderate to high erosion. Orange areas (from 0.25 to $1 \mathrm{~cm}$ ) predominate over the fewer and scattered reddish areas (from 1 to $5 \mathrm{~cm}$ ) (Figure 15). Mainly bare soil on recently tilled fallow lands without vegetation coverage (Image 1 and the left part of Image 4 in Figure 14), forming rills and gullies. - Purple areas: areas with very high erosion (from 5 to $6.21 \mathrm{~cm}$ ). There are only a few scattered points with no relevance in the global erosion values (Figure 15).

Some plots were tilled about three weeks before the storms in STM-2 and did not show the usual water erosion patterns (Figure 15) but a combined effect of tillage and water erosion. In addition to the usual pattern of water erosion following the drainage network, another pattern can be observed showing high erosion values in convex areas on low slopes (sub-watershed border areas), characteristic of tillage erosion.

Hence, even if no tillage works were done in the STM-2 period, the effects of the previous tillage became evident with the first storm and increased the erosion rates in zones where no water erosion was expected.

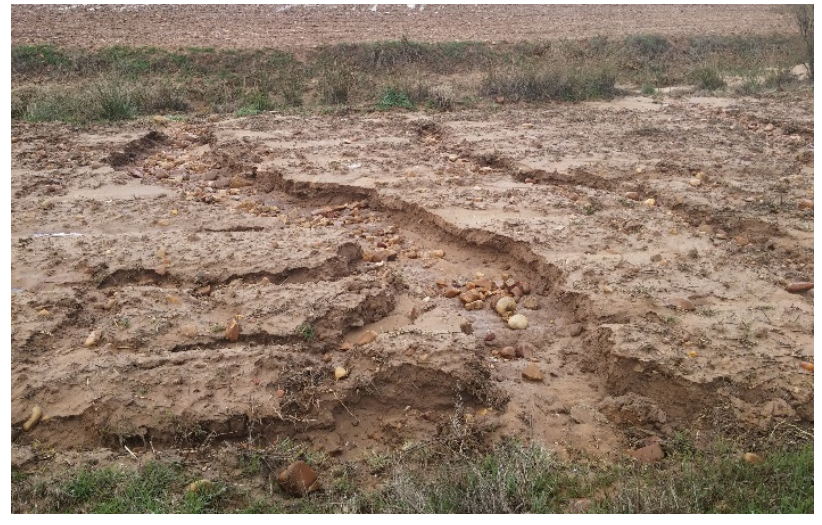

Image 1: Erosion processes. Example of a red zone

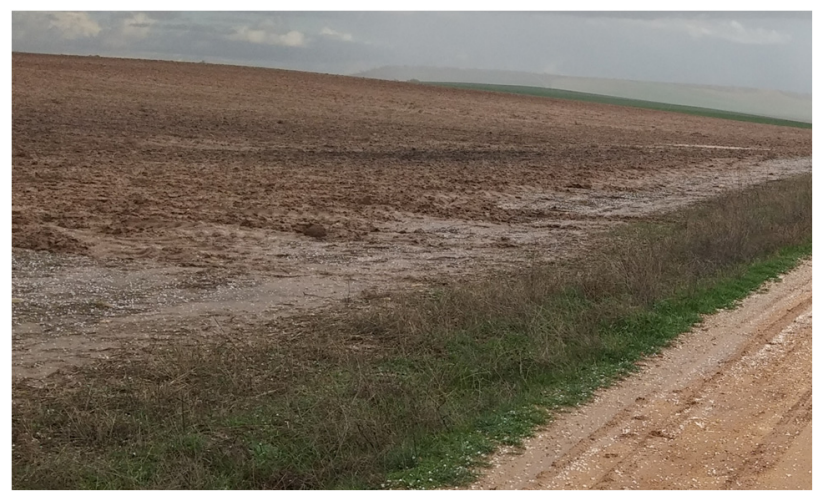

Image 3: Sedimentation processes. Example of a dark green area

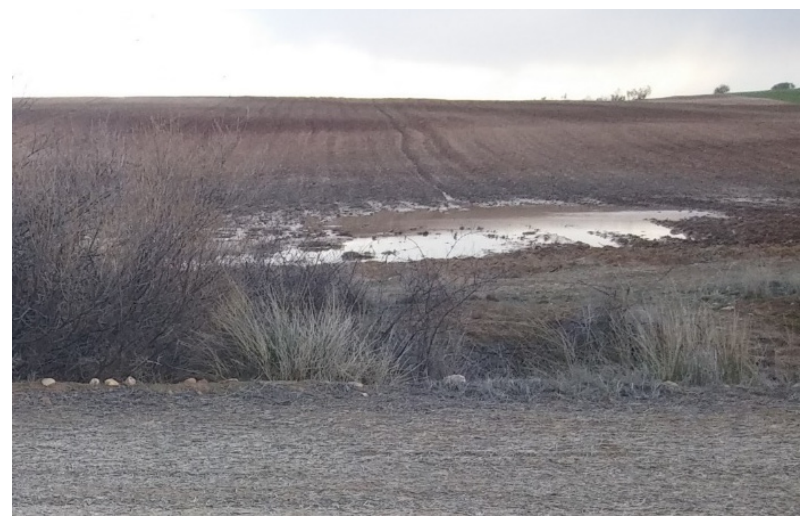

Image 2: Flooded area. Example of a dark green zone

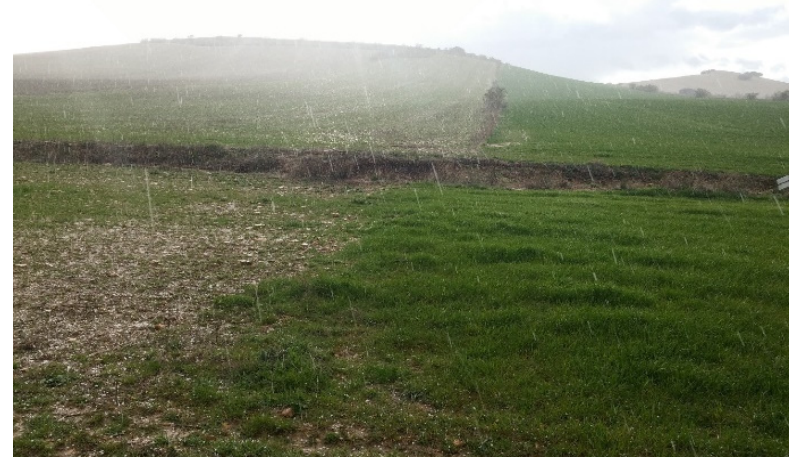

Image 4: Covered land with slight elevation. Example of a light green area

Figure 13. Selection of field visit pictures from the period STM-1 (28 February-6 March 2018). The sites pictured are marked in Figure 12 STM-1 and were taken from the circle pointing to each callout. 


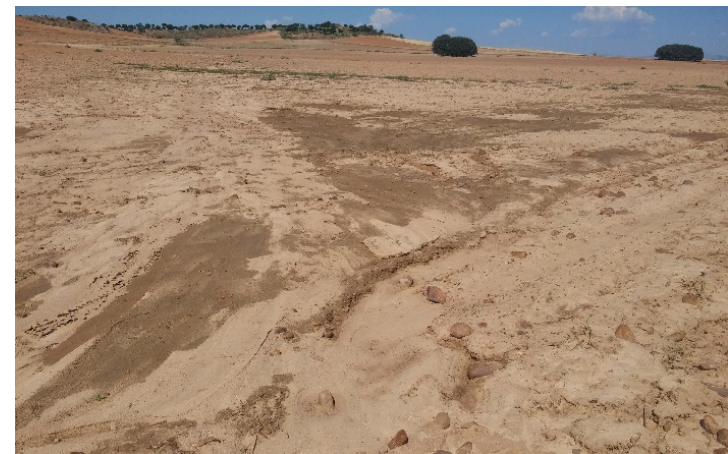

Image 1: Erosion processes. Example of a red zone

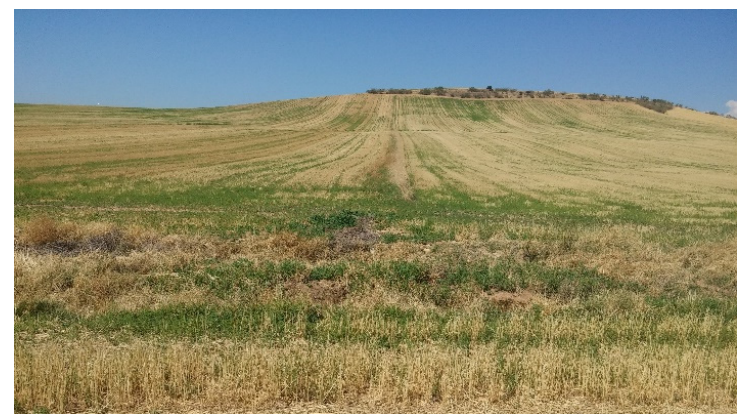

Image 3: Example of wild plants growing between remnants of cereal crops after harvesting

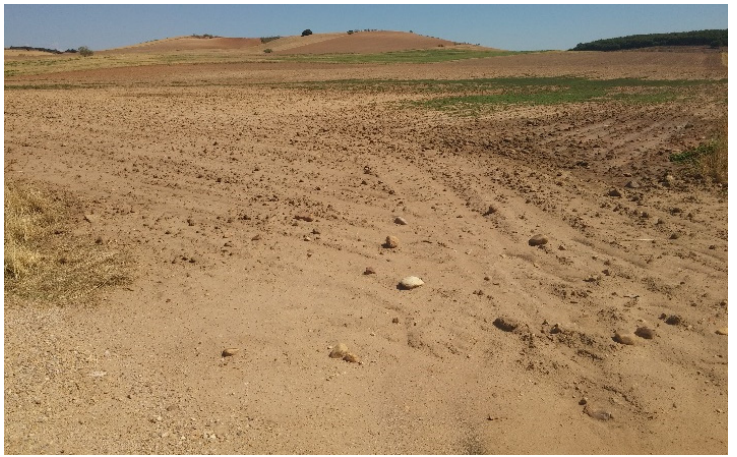

Image 2: Sedimentation processes. Example of dark green areas

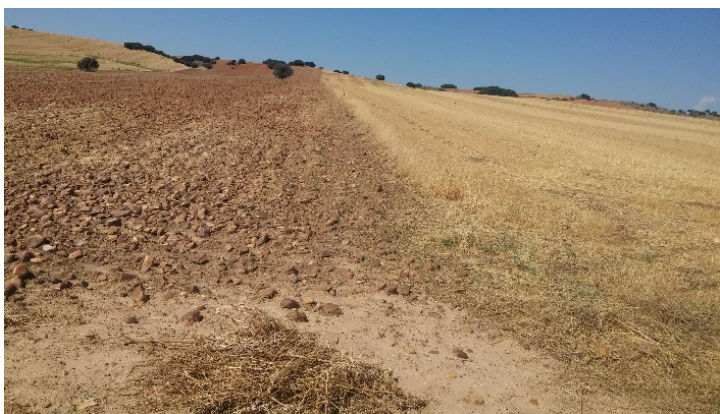

Image 4: Difference between bare soil after tilling (red zones-erosion) and covered by remnants of cereal crops (yellow zones-no erosion)

Figure 14. Selection of field visit pictures. The sites pictured are marked in Figure 12 STM-2 and were taken from the circle pointing to each callout.

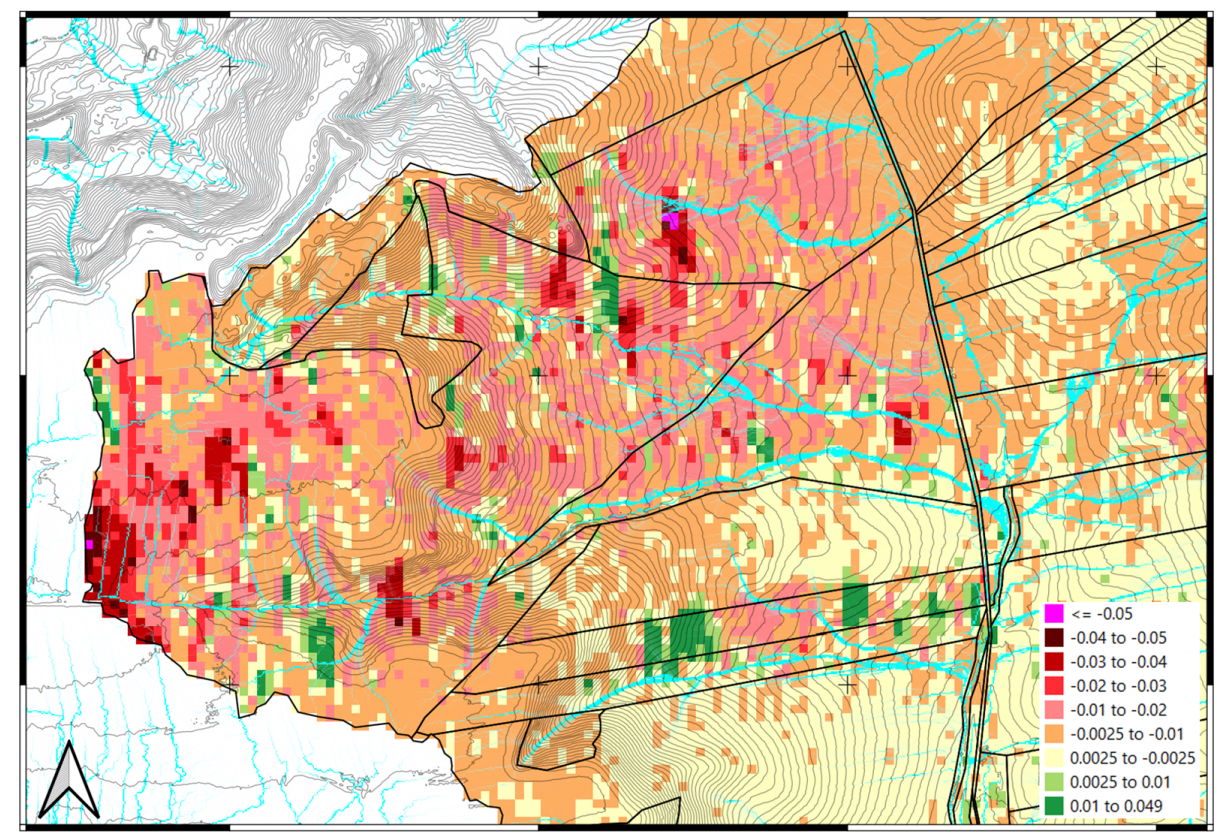

Figure 15. Detail of a plot in STM-2 with the combined effect of a previous tillage with the water erosion of the first storm after tilling. Contour lines every metre and the existing drainage network in blue. Zebra frame segments of $500 \mathrm{~m}$. 


\section{Discussion}

Each of the scenarios studied shows the different capabilities and limitations of the present methodology:

Scenarios AW-1 and AW-2: Scenarios without soil works and without rainfall but with a major change in the height of the cereal crops due to harvesting. No deformations were recorded in the terrain surface, as was expected from the lack of tillage or water erosion, so differential interferometry is not affected by vegetation, such as winter cereal crops, because of the wavelength of the C-Band microwaves used.

Scenario AW-3: Scenario with almost no rain, without harvesting, but with tillage tasks. Deformations were recorded only in the tilled plots, while the global deformation of the basin was near zero, so differential interferometry was able to detect tillage erosion. In this case, coherence loss was considerable, so a clear temporal limitation was detected, as coherence loss in longer periods could be a problem.

Scenario STM-1: Scenario without agricultural tasks, with high rainfall, and with soil coverage in most of the plots. Differential interferometry recorded deformations as expected from water erosion, which was greater in plots without soil coverage.

Scenario STM-2: Scenario without agricultural tasks but with recently tilled plots, high rainfall, and without soil coverage in most of the plots. Deformations recorded with differential interferometry showed that even with lower total rainfall values than STM-1, the erosion values in STM-2 were greater, as the rainfall in STM-1 was spread over several days, and the vegetation coverage exerted a defensive effect. In contrast, most of the rainfall in STM-2 was concentrated in a single day, there was no vegetation cover to serve as a defence against erosion, and the terrain in some plots had been recently tilled, increasing the effect of water erosion. It is worth noting the synergistic effect between water erosion and previously tilled plots, with a much greater erosion value recorded than in nearby non-tilled plots, and the effect of crop remnants as soil protection against erosion.

Scenarios STM-1 and STM-2 show that differential interferometry is capable of detecting water erosion and even the synergy between water erosion and recent tillage and can be used to measure the effects of different factors, such as soil coverage. As in scenario AW-3, coherence loss was considerable, highlighting the temporal limitation of this methodology, so coherence loss over a longer period could be problematic.

In any case, the temporal limitation due to coherence loss could be solved by studying longer periods as a sum of shorter periods as long as coherence loss is limited in each of the shorter periods.

Another factor to take into account is the differences in soil moisture between acquisitions. In scenario STM-1, the moisture conditions varied widely between acquisitions and were quite dry at first and saturated and even waterlogged in some areas in the second. Moisture conditions have an effect on acquisition (the wetter the soil, the lower the penetrating capabilities of the C-Band microwaves), so in this case, erosion may have been underestimated in some areas. This is the most likely the reason for the light green areas in Figure 12 with a slight elevation recorded that does not correspond to sedimentation processes and may explain why the mean value of basin deformation is almost zero and not a negative value. To eradicate this effect, a longer time series should be studied to obtain the effect of moisture on measurements in this basin, or-even better-high-coherence points should be provided and used in the affected zones to measure their distortion in the deformation band.

The use of the NDVI combined with the coherence band allowed the researchers (verified with fieldwork) to identify the events related to the erosion/sedimentation in each scenario (Table 5). 
Table 5. Event identification.

\begin{tabular}{|c|c|c|c|c|}
\hline Coherence Loss & NDVI & Deformation & Precipitation & Event \\
\hline No & Fall & No & - & Harvesting \\
\hline Local (plots) & - & Local (plots) & No & Tillage \\
\hline Yes & - & Yes & Yes & Storm \\
\hline Yes + local * & - & Yes + local * & Yes & Storm + Tillage \\
\hline
\end{tabular}

*Yes + local: General incidence with local increments in plots not due to difference in soil coverage.

\section{Conclusions}

The results of this work show that erosion monitoring in agricultural basins is possible with differential interferometry over Sentinel-1 TopSAR images. Its capabilities have been successfully tested in different conditions related to agricultural tasks without precipitation and storm events.

Two different scenarios were analysed in the case of agricultural tasks without precipitation: harvesting and tillage. In harvesting scenarios without precipitation, no erosion or sedimentation was detected, so changes in cereal crop height do not significantly modify vertical deformation measurements, and there is no evidence of erosion processes in this scenario. For the tillage scenario without rain, local deformations were detected inside plots, but there was no global basin deformation, which is consistent with the tillage erosion expected.

Two different time periods, including storm events with heavy rain, were analysed. The analyses conducted using satellite images during both periods showed erosion and sedimentation processes. These results agree with the information gathered during the field visits, which revealed evidence, such as rills and gullies (erosion), sedimentation areas, and vegetation coverage, in areas with less erosion measurement (even the remnants of cereal crops after harvesting demonstrated protection capabilities against erosion). Plots previously tilled before STM-2 deserve a special mention. Without a direct tillage erosion measurement (no tilling was done during the period but some weeks before), an increase was observed in the expected water erosion due to the combined effect of the previously tilled terrain with the first storm after tilling.

The output erosion raster has a cell size of $13.93 \times 13.93 \mathrm{~m}$, a good resolution for basin scale erosion studies, and sentinel satellites have a frequency that provides images of a given zone every six days (12 if using the same satellite to avoid system differences). This, combined with the free availability of Sentinel-1 TopSAR images, points to differential interferometry as a powerful tool for the analysis and management of erosion in agricultural basins.

It not only makes it possible to study erosion and sedimentation processes but even to test the efficiency of anti-erosion measures in the field and verify the results of different management practices over time. However, some issues still require further implementation and consideration, such as the influence of the soil moisture condition between both acquisitions.

The capacity of differential interferometry for monitoring basin erosion over Sentinel-1 TopSAR images, combined with the interpretation of its coherence band and the NDVI index obtained from Sentinel-2, drastically minimizes the field visits required. It also allows large areas to be monitored with minimum effort and only one qualified professional to interpret the combined information from the deformation/coherence/NDVI raster and distinguish between water and tillage erosion/sedimentation processes from other processes, such as subsidence, landslides, or any other event capable of deforming the Earth's surface.

Author Contributions: Conceptualization: F.A.S.-C., J.R.M.d.S., E.G. and F.A. Methodology: F.A.S.C., M.T.G.-V. and F.A. Software: F.A.S.-C. Validation: F.A.S.-C., J.R.M.d.S., E.G. and F.A. Formal Analysis: F.A.S.-C., M.T.G.-V. and J.M.F. Investigation: F.A.S.-C. and A.I.G. Resources: F.A.S.-C., A.I.G. and F.A. Data Curation: F.A.S.-C. Writing-Original Draft Preparation: F.A.S.-C. Writing-Review \& 
Editing: F.A.S.-C., J.R.M.d.S., M.T.G.-V., E.G., J.M.F., A.I.G. and F.A. Visualization: F.A.S.-C. and J.M.F. Supervision: F.A. Project Administration: F.A. Funding Acquisition: F.A. All authors have read and agreed to the published version of the manuscript.

Funding: The authors have requested the publication assistance offered by the Universidad Politécnica de Madrid with the "PROGRAMA PROPIO DE I+D+I 2021-CONVOCATORIA DE AYUDAS PARA LA PUBLICACION EN ACCESO ABIERTO EN REVISTAS Q1".

Institutional Review Board Statement: Not applicable.

Informed Consent Statement: Not applicable.

Data Availability Statement: The data presented in this study are available on request from the corresponding author. The data are not publicly available due to the large volume of information. Sentinel-1 and Sentinel-2 dataset used in the present study are available at https: / scihub.copernicus. eu/ (accessed on 16 October 2021).

Acknowledgments: The "Rafael Dal-Ré/TRAGSA" Chair in the Universidad Politécnica de Madrid provided the grant "Ayuda a la Realización de Tesis Doctorales 2017-2018" to Francisco A. SánchezCrespo to carry out this work. The European Space Agency (ESA) freely distributes the software (ESA SNAP) and the data (Sentinel-1 TopSAR and Sentinel-2 images) used in this work. Stanford University freely distributes the SNAPHU algorithm (Copyright 2002-2020 Board of Trustees, Leland Stanford Jr. University) used to unwrap the phase of SAR images. The Cygwin Authors freely distributes the Cygwin (Copyright ( C Cygwin authors) package used in this work to run the SNAPHU algorithm in a Microsoft Windows environment.

Conflicts of Interest: The authors declare no conflict of interest.

\section{References}

1. Panagos, P.; Borrelli, P.; Poesen, J.; Ballabio, C.; Lugato, E.; Meusburger, K.; Montanarella, L.; Alewell, C. The new assessment of soil loss by water erosion in Europe. Environ. Sci. Policy 2015, 54, 438-447. [CrossRef]

2. Martín-Fernández, L.; Martínez-Núñez, M. An empirical approach to estimate soil erosion risk in Spain. Sci. Total Environ. 2011, 409, 3114-3123. [CrossRef]

3. Rodriguez-Lloveras, X.; Buytaert, W.; Benito, G. Land use can offset climate change induced increases in erosion in Mediterranean watersheds. Catena 2016, 143, 244-255. [CrossRef]

4. Rodrigo-Comino, J.; Martínez-Hernández, C.; Iserloh, T.; Cerdà, A. Contrasted Impact of Land Abandonment on Soil Erosion in Mediterranean Agriculture Fields. Pedosphere 2018, 28, 617-631. [CrossRef]

5. Van Leeuwen, C.C.; Cammeraat, E.L.; de Vente, J.; Boix-Fayos, C. The evolution of soil conservation policies targeting land abandonment and soil erosion in Spain: A review. Land Use Policy 2019, 83, 174-186. [CrossRef]

6. Van Oost, K.; Govers, G.; De Alba, S.; Quine, T.A. Tillage erosion: A review of controlling factors and implications for soil quality. Prog. Phys. Geogr. 2006, 30, 443-466. [CrossRef]

7. De Vente, J.; Poesen, J. Predicting soil erosion and sediment yield at the basin scale: Scale issues and semi-quantitative models. Earth-Sci. Rev. 2005, 71, 95-125. [CrossRef]

8. Stroosnijder, L. Measurement of erosion: Is it possible? Catena 2005, 64, 162-173. [CrossRef]

9. Savabi, M.R.; Rawls, W.J.; Knight, R.W. Water erosion prediction project (WEPP) rangeland hydrology component evaluation on a Texas range site. Rangel. Ecol. Manag. J. Range Manag. Arch. 1995, 48, 535-541. [CrossRef]

10. King, C.; Baghdadi, N.; Lecomte, V.; Cerdan, O. The application of remote-sensing data to monitoring and modelling of soil erosion. Catena 2005, 62, 79-93. [CrossRef]

11. Baartman, J.E.; Jetten, V.G.; Ritsema, C.J.; de Vente, J. Exploring effects of rainfall intensity and duration on soil erosion at the catchment scale using openLISEM: Prado catchment, SE Spain. Hydrol. Process. 2012, 26, 1034-1049. [CrossRef]

12. Jetten, V.; Govers, G.; Hessel, R. Erosion models: Quality of spatial predictions. Hydrol. Process. 2003, 17, 887-900. [CrossRef]

13. Vrieling, A. Satellite remote sensing for water erosion assessment: A review. Catena 2006, 65, 2-18. [CrossRef]

14. Kuhn, N.J.; Greenwood, P.; Fister, W. Use of field experiments in soil erosion research. In Developments in Earth Surface Processes; Elsevier: Amsterdam, The Netherlands, 2014; Volume 18, pp. 175-200. [CrossRef]

15. Martinez, V.; Garcia, A.I.; Ayuga, F. Distributed routing techniques developed on GIS for generating synthetic unit hydrographs. Trans. ASAE 2002, 45, 1825. [CrossRef]

16. Vicente-Guillén, J.; Ayuga-Téllez, E.; Otero, D.; Chávez, J.L.; Ayuga, F.; García, A.I. Performance of a Monthly Streamflow Prediction Model for Ungauged Watersheds in Spain. Water Resour. Manag. 2012, 26, 3767-3784. [CrossRef]

17. Luleva, M.I.; Van Der Werff, H.; Van Der Meer, F.; Jetten, V. Gaps and opportunities in the use of remote sensing for soil erosion assessment. Chemistry 2012, 21, 748-764.

18. Bretar, F.; Chauve, A.; Bailly, J.S.; Mallet, C.; Jacome, A. Terrain surfaces and 3D landcover classification from small footprint full-waveform lidar data: Application to badlands. Hydrol. Earth Syst. Sci. 2009, 13, 1531-1544. [CrossRef] 
19. Peter, H.; Jäggi, A.; Fernández, J.; Escobar, D.; Ayuga, F.; Arnold, D.; Wermuth, M.; Hackel, S.; Otten, M.; Simons, W.; et al. Sentinel-1A-first precise orbit determination results. Adv. Space Res. 2017, 60, 879-892. [CrossRef]

20. Berger, M.; Aschbacher, J. Preface: The Sentinel missions-new opportunities for science. Remote Sens. Environ. 2012, 120, 1-2. [CrossRef]

21. Geudtner, D.; Torres, R.; Snoeij, P.; Davidson, M.; Rommen, B. Sentinel-1 system capabilities and applications. In Proceedings of the 2014 IEEE International Geoscience and Remote Sensing Symposium (IGARSS), Quebec City, QC, Canada, 13-18 July 2014; pp. 1457-1460. [CrossRef]

22. Zhou, X.; Chang, N.-B.; Li, S. Applications of SAR interferometry in earth and environmental science research. Sensors 2009, 9, 1876-1912. [CrossRef] [PubMed]

23. González, P.J.; Bagnardi, M.; Hooper, A.J.; Larsen, Y.; Marinkovic, P.; Samsonov, S.V.; Wright, T.J. The $2014-2015$ eruption of Fogo volcano: Geodetic modeling of Sentinel-1 TOPS interferometry. Geophys. Res. Lett. 2015, 42, 9239-9246. [CrossRef]

24. Massonnet, D.; Feigl, K.L. Radar interferometry and its application to changes in the Earth's surface. Rev. Geophys. 1998, 36, 441-500. [CrossRef]

25. Salvi, S.; Stramondo, S.; Funning, G.J.; Ferretti, A.; Sarti, F.; Mouratidis, A. The Sentinel-1 mission for the improvement of the scientific understanding and the operational monitoring of the seismic cycle. Remote Sens. Environ. 2012, 120, 164-174. [CrossRef]

26. Osmanoğlu, B.; Sunar, F.; Wdowinski, S.; Cabral-Cano, E. Time series analysis of InSAR data: Methods and trends. ISPRS J. Photogramm. Remote Sens. 2016, 115, 90-102. [CrossRef]

27. Barboux, C.; Strozzi, T.; Delaloye, R.; Wegmüller, U.; Collet, C. Mapping slope movements in Alpine environments using TerraSAR-X interferometric methods. ISPRS J. Photogramm. Remote. Sens. 2015, 109, 178-192. [CrossRef]

28. Colesanti, C.; Wasowski, J. Investigating landslides with space-borne Synthetic Aperture Radar (SAR) interferometry. Eng. Geol. 2006, 88, 173-199. [CrossRef]

29. Squarzoni, C.; Delacourt, C.; Allemand, P. Nine years of spatial and temporal evolution of the La Valette landslide observed by SAR interferometry. Eng. Geol. 2003, 68, 53-66. [CrossRef]

30. Smith, L.C.; Alsdorf, D.E.; Magilligan, F.J.; Gomez, B.; Mertes, L.A.K.; Smith, N.D.; Garvin, J.B. Estimation of erosion, deposition, and net volumetric change caused by the 1996 Skeiðarársandur jökulhlaup, Iceland, from synthetic aperture radar interferometry. Water Resour. Res. 2000, 36, 1583-1594. [CrossRef]

31. Spreckels, V.; Wegmüller, U.; Strozzi, T.; Musiedlak, J.; Wichlacz, H.C. Detection and observation of underground coal mininginduced surface deformation with differential SAR interferometry. In Proceedings of the ISPRS Workshop "High Resolution Mapping from Space 2001", Hanover, Germany, 19-21 September 2001; pp. 227-234.

32. Loesch, E.; Sagan, V. SBAS analysis of induced ground surface deformation from wastewater injection in East Central Oklahoma, USA. Remote Sens. 2018, 10, 283. Available online: https:/ /www.mdpi.com/2072-4292/10/2/283 (accessed on 30 September 2021). [CrossRef]

33. Anghel, A.; Vasile, G.; Boudon, R.; d'Urso, G.; Girard, A.; Boldo, D.; Bost, V. Combining spaceborne SAR images with 3D point clouds for infrastructure monitoring applications. ISPRS J. Photogramm. Remote Sens. 2016, 111, 45-61. [CrossRef]

34. Di Martire, D.; Iglesias, R.; Monells, D.; Centolanza, G.; Sica, S.; Ramondini, M.; Pagano, L.; Mallorquí, J.J.; Calcaterra, D. Comparison between Differential SAR interferometry and ground measurements data in the displacement monitoring of the earth-dam of Conza della Campania (Italy). Remote Sens. Environ. 2014, 148, 58-69. [CrossRef]

35. Sánchez-Crespo, F.A.; Ayuga, F.; García, A.I. Interferometry as a tool for localized study of runoff erosion. In Proceedings of the IX Iberian Congress on Agro-Engineering, Bragança, Portugal, 4-6 September 2017.

36. Sánchez-Crespo, F.A.; Gallego, E.; Fuentes, J.M.; Ayuga, F.; García, A.I. Differential Interferometry as a Tool for Localized Study of Runoff Erosion. In Proceedings of the EurAgEng 2018 Conference, Wageningen, The Netherlands, 8-11 July 2018.

37. Lu, S.; Wang, Z.; Hu, Y.; Liu, B.; Liu, J.E. Effectiveness and durability of polyacrylamide (PAM) and polysaccharide (JAG c 162) in reducing soil erosion under simulated rainfalls. Water 2018, 10, 257. [CrossRef]

38. Torres, R.; Snoeij, P.; Geudtner, D.; Bibby, D.; Davidson, M.; Attema, E.; Potin, P.; Rommen, B.Ö.; Floury, N.; Brown, M.; et al. GMES Sentinel-1 mission. Remote Sens. Environ. 2012, 120, 9-24. [CrossRef]

39. Paloscia, S.; Macelloni, G.; Pampaloni, P.; Sigismondi, S. The potential of C-and L-band SAR in estimating vegetation biomass: The ERS-1 and JERS-1 experiments. IEEE Trans. Geosci. Remote Sens. 1999, 37, 2107-2110. [CrossRef]

40. Yague-Martinez, N.; Prats-Iraola, P.; Gonzalez, F.R.; Brcic, R.; Shau, R.; Geudtner, D.; Eineder, M.; Bamler, R. Interferometric Processing of Sentinel-1 TOPS Data. IEEE Trans. Geosci. Remote Sens. 2016, 54, 2220-2234. [CrossRef]

41. De Zan, F.; Guarnieri, A.M. TOPSAR: Terrain Observation by Progressive Scans. Geoscience and Remote Sensing. IEEE Trans. 2006, 44, 2352-2360.

42. Tamm, T.; Zalite, K.; Voormansik, K.; Talgre, L. Relating Sentinel-1 interferometric coherence to mowing events on grasslands. Remote Sens. 2016, 8, 802. [CrossRef]

43. Koch, B. Status and future of laser scanning, synthetic aperture radar and hyperspectral remote sensing data for forest biomass assessment. ISPRS J. Photogramm. Remote Sens. 2010, 65, 581-590. [CrossRef]

44. Veloso, A.; Mermoz, S.; Bouvet, A.; Le Toan, T.; Planells, M.; Dejoux, J.F.; Ceschia, E. Understanding the temporal behavior of crops using Sentinel-1 and Sentinel-2-like data for agricultural applications. Remote Sens. Environ. 2017, 199, 415-426. [CrossRef]

45. Pan, Z.; Huang, J.; Zhou, Q.; Wang, L.; Cheng, Y.; Zhang, H.; Blackburn, G.A.; Yan, J.; Liu, J. Mapping crop phenology using NDVI time-series derived from HJ-1 A/B data. Int. J. Appl. Earth Obs. Geoinf. 2015, 34, 188-197. [CrossRef] 
46. Lunetta, R.S.; Knight, J.F.; Ediriwickrema, J.; Lyon, J.G.; Worthy, L.D. Land-cover change detection using multi-temporal MODIS NDVI data. Remote Sens. Environ. 2006, 105, 142-154. [CrossRef]

47. Ferreti, A.; Monti-Guarnieri, A.; Prati, C.; Rocca, F. TM-19 InSAR Principles: Guidelines for SAR Interferometry Processing and Interpretation. European Space Agency Publications ESTEC (The Netherlands). 2007. Available online: http://www.esa.int/ About_Us/ESA_Publications (accessed on 16 October 2021).

48. Touzi, R.; Lopes, A.; Bruniquel, J.; Vachon, P.W. Coherence estimation for SAR imagery. IEEE Trans. Geosci. Remote Sens. 1999, 37, 135-149. [CrossRef]

49. Martone, M.; Bräutigam, B.; Rizzoli, P.; Gonzalez, C.; Bachmann, M.; Krieger, G. Coherence evaluation of TanDEM-X interferometric data. ISPRS J. Photogramm. Remote Sens. 2012, 73, 21-29. [CrossRef]

50. Engdahl, M.; Minchella, A.; Marinkovic, P.; Veci, L.; Lu, J. NEST: An ESA open source toolbox for scientific exploitation of SAR data. In Proceedings of the 2012 IEEE International Geoscience and Remote Sensing Symposium (IGARSS), Munich, Germany, 22-27 July 2012; pp. 5322-5324. [CrossRef]

51. Zuhlke, M.; Fomferra, N.; Brockmann, C.; Peters, M.; Veci, L.; Malik, J.; Regner, P. SNAP (sentinel application platform) and the ESA sentinel 3 toolbox. In Proceedings of the Sentinel-3 for Science Workshop, Venice, Italy, 2-5 June 2015; Volume 734, p. 21.

52. Chen, C.W.; Zebker, H.A. Network approaches to two-dimensional phase unwrapping: Intractability and two new algorithms. J. Opt. Soc. Am. A 2000, 17, 401-414. [CrossRef] [PubMed]

53. Chen, C.W.; Zebker, H.A. Two-dimensional phase unwrapping with use of statistical models for cost functions in nonlinear optimization. J. Opt. Soc. Am. A 2001, 18, 338-351. [CrossRef] [PubMed]

54. Chen, C.W.; Zebker, H.A. Phase unwrapping for large SAR interferograms: Statistical segmentation and generalized network models. IEEE Trans. Geosci. Remote Sens. 2002, 40, 1709-1719. [CrossRef]

55. Mancon, S.; Guarnieri, A.M.; Tebaldini, S. Sentinel-1 precise orbit calibration and validation. In Proceedings of the FRINGE, Frascati, Italy, 23-27 March 2015; pp. 1-4.

56. Goldstein, R.M.; Werner, C.L. Radar interferogram filtering for geophysical applications. Geophys. Res. Lett. 1998, 25, 4035-4038. [CrossRef]

57. Small, D.; Pasquali, P.; Fuglistaler, S. A comparison of phase to height conversion methods for SAR interferometry. In Proceedings of the IGARSS'96. 1996 International Geoscience and Remote Sensing Symposium, Lincoln, NE, USA, 31 May 1996; Volume 1, pp. 342-344. [CrossRef]

58. Richards, M.A. A Beginner's Guide to interferometric SAR concepts and signal processing [AESS tutorial IV]. IEEE Aerosp. Electron. Syst. Mag. 2007, 22, 5-29. [CrossRef]

59. Rodriguez-Cassola, M.; Prats-Iraola, P.; De Zan, F.; Scheiber, R.; Reigber, A.; Geudtner, D.; Moreira, A. Doppler-related distortions in TOPS SAR images. IEEE Trans. Geosci. Remote Sens. 2015, 53, 25-35. [CrossRef]

60. Sánchez-Crespo, F.A.; Gomez-Villarino, M.T.; Ayuga, F.; García, A.I. Differential Interferometry as a tool for localized study of runoff erosion. In Proceedings of the X Iberian Congress on Agro-Engineering, Huesca, Spain, 31 December 2019.

61. Lloyd, D. A phenological classification of terrestrial vegetation cover using shortwave vegetation index imagery. Int. J. Remote Sens. 1990, 11, 2269-2279. [CrossRef]

62. Rouse, J.W.; Haas, R.H.; Schell, J.A.; Deering, D.W.; Harlan, J.C. Monitoring the Vernal Advancements and Retrogradation of Natural Vegetation NASA/GSFC; Final Report; Texas A\&M University Remote Sensing Center: Greenbelt, MD, USA, $1974 ;$ pp. 1-137.

63. Jakubauskas, M.E.; Legates, D.R.; Kastens, J.H. Crop identification using harmonic analysis of time-series AVHRR NDVI data. Comput. Electron. Agric. 2002, 37, 127-139. [CrossRef] 